\title{
Nanostructured $\mathrm{ZnFe}_{2} \mathrm{O}_{4}$ as Anode Material for Lithium-Ion Batteries: Ionic Liquid-Assisted Synthesis and Performance Evaluation with Special Emphasis on Comparative Metal Dissolution
}

\author{
Haiping Jia, Richard Kloepsch, Xin He, Marco Evertz, Sascha Nowak, \\ Jie Li, Martin Winter* and Tobias Placke* \\ University of Münster, MEET Battery Research Center, Institute of Physical Chemistry, \\ Corrensstr. 46, 48149 Münster, Germany \\ * Corresponding author: E-mail: tobiasplacke@uni-muenster.de, martin.winter@uni-muenster.de \\ Tel.: +49 251 83-36701, Fax: +49 251 83-36032; Tel.: +49 251 83-36826, Fax: +49 251 83-36032
}

Received: 13-01-2016

In memoriam of Janez (Janko) Jamnik, a brilliant scientist with an exceptional combination of great leadership capabilities and a friendly and kind personality

\begin{abstract}
In this work, a $\mathrm{ZnFe}_{2} \mathrm{O}_{4}$ anode material was successfully synthesized by a novel ionic liquid-assisted synthesis method followed by a carbon coating procedure. The as-prepared $\mathrm{ZnFe}_{2} \mathrm{O}_{4}$ particles demonstrate a relatively homogeneous particle size distribution with particle diameters ranging from 40 to $80 \mathrm{~nm}$. This material, which is well known to offer an interesting combination of an alloying and conversion mechanism, is capable of accommodating nine equivalents of lithium per unit formula, resulting in a high specific capacity $\left(\geq 1,000 \mathrm{mAh} \mathrm{g}^{-1}\right)$. The resulting composite anode material displayed a stable capacity of ca. 1,091 $\mathrm{mAh} \mathrm{g}^{-1}$ for 190 cycles at a medium de-lithiation potential of $1.7 \mathrm{~V}$ and at a charge/discharge rate of $1 \mathrm{C}$. Furthermore, the material displays an excellent high rate capability up to $20 \mathrm{C}$, displaying a reversible capacity of still $216 \mathrm{mAh} \mathrm{g}^{-1}$. Studies on $\mathrm{Fe}$ and $\mathrm{Zn}$ losses of the $\mathrm{ZnFe}_{2} \mathrm{O}_{4}$ active material by dissolution in the electrolyte were performed and compared to those of silicon-, germanium- and tin-based high-capacity anode materials. In conclusion, ion dissolution from metal containing anode materials should not be underestimated in view of its impact on the overall cell performance and cycling stability.
\end{abstract}

Keywords: $\mathrm{ZnFe}_{2} \mathrm{O}_{4} / \mathrm{C}$ composite, anode material, ionic liquid, metal dissolution, lithium-ion batteries

\section{Introduction}

The ever-growing demand for the next-generation lithium-ion batteries (LIBs) with high specific energy $\left(\mathrm{Wh} \mathrm{kg}^{-1}\right) /$ energy density $\left(\mathrm{Wh} \mathrm{L}^{-1}\right)$ as well as high power performance has prompted widespread research to develop novel electrode materials for both the anode and cathode. Currently, commercialized graphite anode materials apparently cannot satisfy the demand of high-energy battery systems due to the relatively low theoretical specific capacity $\left(372 \mathrm{mAh} \mathrm{g}^{-1}\right)$ and poor rate capability, in particular during charge. ${ }^{2,3}$ However, considering that the energy content of a battery cell is the product of capacity and cell voltage, it is difficult to find an anode material other than carbon, which possesses such a low (and constant) discharge potential as graphite.

Since academic search for alternative anode materials typically focuses on capacity improvements, the first look at novel materials always goes to their gravimetric and volumetric capacities (Figure 1a and 1b). In this respect, $\mathrm{Si}, \mathrm{Sn}, \mathrm{Ge}$ and several types of metal oxides, such as $\mathrm{ZnFe}_{2} \mathrm{O}_{4}$, seem to be very promising candidates for the negative electrode. In terms of gravimetric capacity, $\mathrm{Si}$ is the most promising material showing the highest storage capability of ca. $3,500 \mathrm{mAh} \mathrm{g}^{-1}$, while for the volumetric capacity also various metal oxides are of strong interest since they display even higher capacity values than $\mathrm{Si}$ (Figure 1b), i.e. between ca. 3,000 and 5,000 $\mathrm{mAh} \mathrm{cm}^{-3}$. 
However, it has to be considered that the practical volumetric capacity not only depends on the material, but also on the electrode structure and cell design and may change during charge/discharge cycling. Besides the capacity, also the adundance and costs of the anode materials need to be considered (Figure 1c and 1d). In this respect, in particular the high costs and low abundance of Sn and Ge do only allow the use for niche applications. Currently, the research on novel anode materials, considering their electrochemical characteristics, is mainly limited to capacity improvements rather than energy and power density improvements and accordingly, rate capability and not power capability is the measure that counts in most academic reports.

There are mainly three types of anode materials for LIBs according to the different lithiation storage mechanisms: (I) intercalation materials such as graphite ${ }^{6}$ and insertion materials such as $\mathrm{Li}_{4} \mathrm{Ti}_{5} \mathrm{O}_{12}$ spinel oxides or $\mathrm{TiO}_{2}$ anatase ${ }^{7-9}(I I)$ the so called "lithium alloying" materials, such as $\mathrm{Si}$, $\mathrm{Sn}$ and $\mathrm{Ge}$ forming intermetallic phases with $\mathrm{Li},{ }^{10-13}$ which depending on the used metals have various operating discharge potentials, with Si showing the lowest potential $^{11}$ and (III) conversion materials, such as transition metal oxides, -sufides or -nitrides, which store charge via a conversion reaction. The conversion reaction can be generalized by the equation: $M_{\mathrm{a}} X_{\mathrm{b}}+(\mathrm{b} \cdot \mathrm{n}) \mathrm{Li}^{+}+(\mathrm{b} \cdot \mathrm{n}) \mathrm{e}^{-}$ $\rightleftharpoons \mathrm{a} M+\mathrm{b} \mathrm{Li}_{\mathrm{n}} X$, where $M$ is the transition metal, $X$ is the anion (most commonly oxygen in the case of anode materials) and $\mathrm{n}$ is the formal oxidation state of $X .^{14,15}$ Conversion materials, in particular those using light weight metals $M$, typically show relatively high specific capacities. However, these capacities are usually only available over a large and in average relatively high potential range, negatively affecting the energy of a full LIB cell. As like for lithium alloying host materials, ${ }^{16}$ the kinetics of the lithium uptake and release reaction will increase with decreasing particle or grain size of the conversion anode material, most likely resulting in an enhanced performance at high charge/discharge rates, especially for nano- and nanostructured materials. The enhanced surface area, however, will lead to an increased electrolyte decomposition, which may have a negative impact on the long-term cycling stability in LIBs.

Among the conversion materials, the nanostructured binary and ternary metal oxides, such as iron oxides (e.g. hematite $\alpha-\mathrm{Fe}_{2} \mathrm{O}_{3}$, spinel $\mathrm{Fe}_{3} \mathrm{O}_{4}$ and $\left.\mathrm{ZnFe}_{2} \mathrm{O}_{4}\right){ }^{17-22}$ manganese oxides (e.g. $\mathrm{MnO}_{2}, \mathrm{Mn}_{3} \mathrm{O}_{4}$ and $\left.\mathrm{ZnMn}_{2} \mathrm{O}_{4}\right)^{23-25}$ and cobalt oxides (e.g. $\mathrm{CoO}, \mathrm{Co}_{3} \mathrm{O}_{4}$ and $\left.\mathrm{ZnCo}_{2} \mathrm{O}_{4}\right)^{26-28}$ have
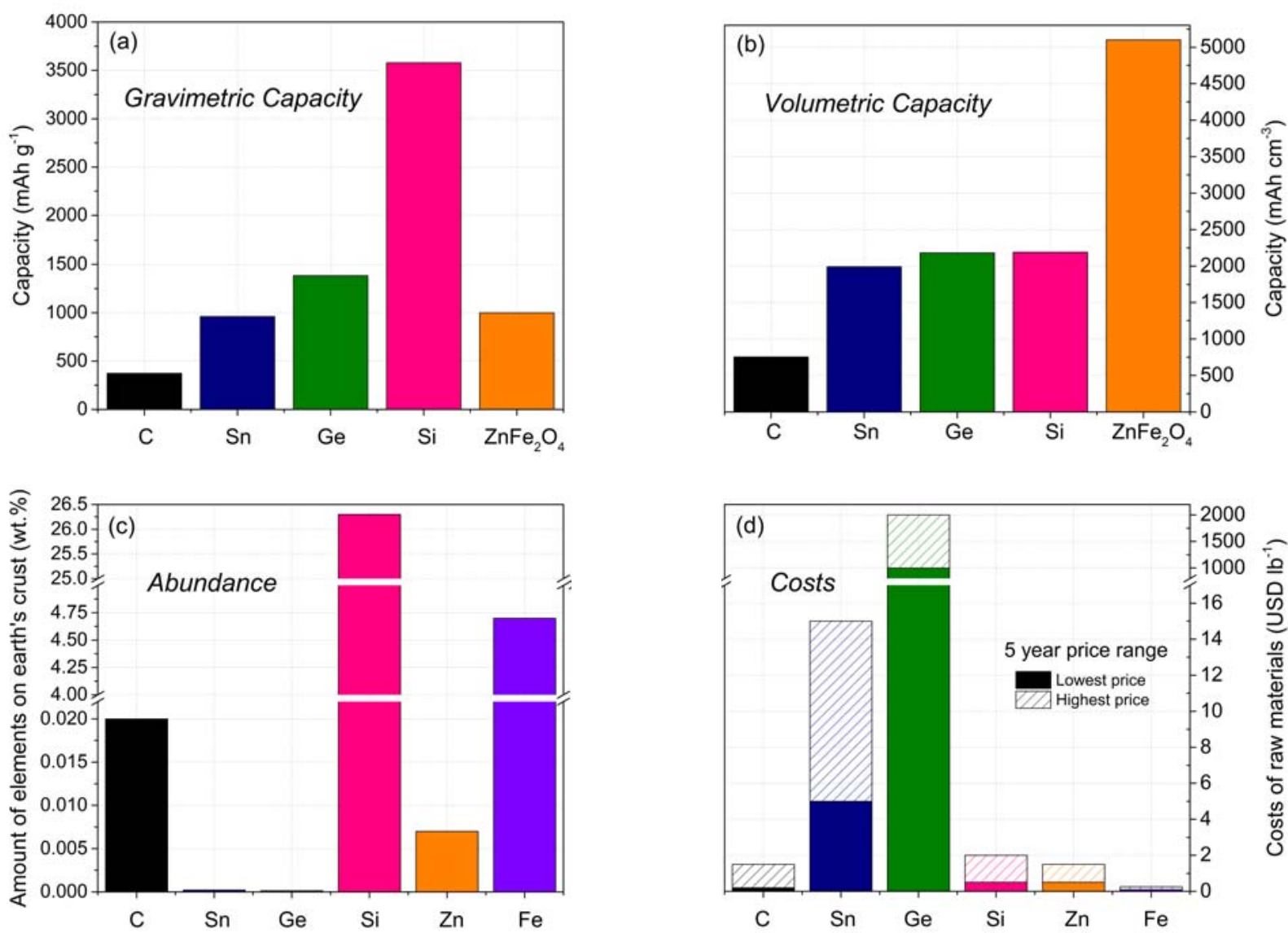

Figure 1. Gravimetric and volumetric lithium storage capacities of different anode materials, abundance of elements (as fraction of earth's crust in wt.\%) and costs of elements (approximate 5-year ranges, exept for Ge which is a 3-year range, according to ${ }^{5}$ ). 
been extensively studied as alternative anode materials for use in LIBs over the past few years. This is related to the fact that there is a large number of possible new material combinations, which provide high specific capacities ranging from ca. 650 to $1,000 \mathrm{mAh} \mathrm{g}^{-1}$.

$\mathrm{Fe}_{3} \mathrm{O}_{4}$, for example, gives a theoretical capacity of $926 \mathrm{mAh} \mathrm{g}^{-1}$, considering the complete reversible formation of four $\mathrm{Li}_{2} \mathrm{O}$ per formula unit. Low cost, environmentally benign as well as biocompatible iron-based oxides ${ }^{29}$ have received increasing interest of scientific investigation. However, the reduced iron during the lithiation process is itself not electrochemically active to $\mathrm{Li}^{+}$. At contrast, $\mathrm{ZnO}$ shows an advantage, because $\mathrm{Zn}$, as the product of $\mathrm{ZnO}$ reactions with $\mathrm{Li}$, can reversibly alloy with $\mathrm{Li}$. Thus, the theoretical capacity of these transition metal oxides can be further increased by replacing one iron atom by an element which can reversibly form an alloy with lithium, such as zinc in addition to the still ongoing conversion reaction. ${ }^{30-32}$ This would result in an enhanced theoretical capacity of ca. $1000 \mathrm{mAh} \mathrm{g}^{-1}$, according to the reversible reaction involving nine lithium ions per formula unit of $\mathrm{ZnFe}_{2} \mathrm{O}_{4}$.

Chen et al., for the first time, reported the lithium insertion reaction in spinel zinc ferrite using a chemical synthesis approach with n-butyllithium in hexane. However, only about $0.5 \mathrm{Li}^{+}$per formula unit could be inserted in this host material by n-buli/hexane and, moreover, this reaction was found to be irreversible. ${ }^{33}$ Nuli et al. reported the reversible lithium uptake of nanocrystalline thin films of $\mathrm{ZnFe}_{2} \mathrm{O}_{4}$, which presented a reversible capacity of $560 \mathrm{mAh} \mathrm{g}^{-1}$, corresponding to an uptake of $5 \mathrm{Li}$ per $\mathrm{ZnFe}_{2} \mathrm{O}_{4}$. This material demonstrated a rather poor cycling performance since only a capacity retention of $78 \%$ was obtained after 100 cycles. ${ }^{34}$ Deng et al.

Table 1. Summary of the synthesis methods for $\mathrm{ZnFe}_{2} \mathrm{O}_{4}$.

\begin{tabular}{|c|c|c|}
\hline Synthesis method & Example for precursor materials & Synthesis properties \\
\hline \multirow{2}{*}{$\begin{array}{l}\text { Precipitation } \\
\text { method }^{40-42}\end{array}$} & $\begin{array}{l}\mathrm{ZnCl}_{2} ; \mathrm{FeC}_{2} \mathrm{O}_{4} \cdot 2 \mathrm{H}_{2} \mathrm{O} \\
\text { conc. } \mathrm{HNO}_{3} \\
\mathrm{CO}\left(\mathrm{NH}_{2}\right)_{2} \\
\text { (urea) })^{40}\end{array}$ & $\begin{array}{l}\text { - Simple synthesis route (easy to operate) } \\
\text { - Cost-effective preparation } \\
\text { - Calcination at high temperature }\left(900{ }^{\circ} \mathrm{C}\right) \\
\text { - Agglomerated particles }(100-300 \mathrm{~nm})\end{array}$ \\
\hline & $\begin{array}{l}\mathrm{FeSO}_{4} \cdot 7 \mathrm{H}_{2} \mathrm{O} \\
\mathrm{ZnSO}_{4} \cdot 7 \mathrm{H}_{2} \mathrm{O} \\
\mathrm{Na}_{2} \mathrm{C}_{2} \mathrm{O}_{4}^{41}\end{array}$ & $\begin{array}{l}\text { - Porous structure; } \\
\text { - Calcination at high temperature }\left(700^{\circ} \mathrm{C}\right) \\
\text { - Big particles }(\mu \mathrm{m} \text { range })\end{array}$ \\
\hline \multirow{2}{*}{$\begin{array}{c}\text { Hydrothermal / } \\
\text { solvothermal processing }\end{array}$} & $\begin{array}{c}(\mathrm{NH} 4)_{2} \mathrm{Fe}\left(\mathrm{SO}_{4}\right) \\
6 \mathrm{H}_{2} \mathrm{O} ; \mathrm{ZnSO}_{4} \cdot 7 \mathrm{H}_{2} \mathrm{O} \\
\text { glucose }^{36}\end{array}$ & $\begin{array}{l}\text { - Simple synthesis route } \\
\text { - Small primary particles }(10-20 \mathrm{~nm}) \\
\text { - Calcination at high temperature }\left(600{ }^{\circ} \mathrm{C}\right)\end{array}$ \\
\hline & $\begin{array}{l}\mathrm{FeCl}_{3} \cdot 6 \mathrm{H}_{2} \mathrm{O} ; \mathrm{ZnCl}_{2} ; \\
\text { ethylene glycol; } \\
\text { PEG-600; urea }\end{array}$ & $\begin{array}{l}\text { - Without further calcination at high temperatue } \\
\text { - Uniform hollow sphere structure } \\
\text { - Relatively big particle size }(\sim 500 \mathrm{~nm})\end{array}$ \\
\hline $\begin{array}{l}\text { Refluxing } \\
\text { synthesis }^{43}\end{array}$ & $\begin{array}{l}\mathrm{FeCl}_{3} \cdot 6 \mathrm{H}_{2} \mathrm{O} \\
\mathrm{ZnSO}_{4} \cdot 7 \mathrm{H}_{2} \mathrm{O}\end{array}$ & $\begin{array}{l}- \text { - Cost-effective route } \\
\text { - Rapid process } \\
\text { - Very small particles }(\sim 7 \mathrm{~nm})\end{array}$ \\
\hline Microemulsion $^{44}$ & $\begin{array}{l}\mathrm{Zn}\left(\mathrm{NO}_{3}\right)_{2} ; \mathrm{FeSO}_{4} ; \\
\text { CTAB; cyclohexane; } \\
\text { n-pentanol; } \mathrm{H}_{2} \mathrm{C}_{2} \mathrm{O}_{4}\end{array}$ & $\begin{array}{l}\text { - Special morphology (nanorods) } \\
\text { - Calcination at high temperature } \\
\left(500^{\circ} \mathrm{C}\right)\end{array}$ \\
\hline Polymer pyrolysis ${ }^{45}$ & $\begin{array}{l}\mathrm{Zn}\left(\mathrm{NO}_{3}\right)_{2} \cdot 6 \mathrm{H}_{2} \mathrm{O} \\
\mathrm{Fe}\left(\mathrm{NO}_{3}\right) \cdot 9 \mathrm{H}_{2} \mathrm{O} \\
\text { acrylic acid; } \\
\left(\mathrm{NH}_{4}\right)_{2} \mathrm{~S}_{2} \mathrm{O}_{8} \\
\end{array}$ & $\begin{array}{l}\text { - Well distributed particles } \\
\text { - Small primary particles }(30-70 \mathrm{~nm}) \\
\text { - Calcination at high temperature } \\
\left(600^{\circ} \mathrm{C}\right) \\
\end{array}$ \\
\hline Pulsed laser deposition ${ }^{34}$ & $\begin{array}{l}\text { Targets from zinc } \\
\text { and } \\
\text { iron powder }\end{array}$ & $\begin{array}{l}- \text { Small particle size }(40-100 \mathrm{~nm}) \\
\text { - High costs } \\
\text { - Small scale production technique }\end{array}$ \\
\hline Molten salt route ${ }^{46}$ & $\begin{array}{l}\mathrm{ZnSO}_{4} \cdot \mathrm{H}_{2} \mathrm{O} \\
\mathrm{Fe}_{2}\left(\mathrm{SO}_{4}\right)_{3} \\
\mathrm{LiCl} \cdot \mathrm{H}_{2} \mathrm{O}\end{array}$ & $\begin{array}{l}\text { - Simple synthesis route (solid state reaction) } \\
\text { - High reaction temperature }\left(800^{\circ} \mathrm{C}\right) \text {; } \\
\text { - Big particles }(\mu \mathrm{m} \text { range })\end{array}$ \\
\hline Sol-gel method ${ }^{47,48}$ & $\begin{array}{c}\mathrm{Zn}\left(\mathrm{NO}_{3}\right)_{2} \cdot 6 \mathrm{H}_{2} \mathrm{O} \\
\mathrm{Fe}\left(\mathrm{NO}_{3}\right)_{3} \cdot 9 \mathrm{H}_{2} \mathrm{O} \\
\text { Citric acid; Ammonia }\end{array}$ & $\begin{array}{l}\text { - Calcination at high temperature } \\
\left(600-1000^{\circ} \mathrm{C}\right) \\
\text { - Adjustment of } \mathrm{pH} \text { value necessary }\end{array}$ \\
\hline $\begin{array}{l}\text { Ionic liquid-assisted } \\
\text { synthesis method } \\
\text { (this work) }\end{array}$ & $\begin{array}{c}\text { BMIMBF }_{4} ; \text { ethylene alcohol; } \\
\mathrm{Zn}\left(\mathrm{O}_{2} \mathrm{CCH}_{3}\right)_{2} \\
\mathrm{Fe}\left(\mathrm{NO}_{3}\right)_{3}\end{array}$ & $\begin{array}{l}\text { - Simple synthesis route (easy to operate) } \\
\text { - Small particle size }(40-80 \mathrm{~nm}) \\
\text { - Calcination at } 500^{\circ} \mathrm{C}\end{array}$ \\
\hline
\end{tabular}


synthesized the monodispered $\mathrm{ZnFe}_{2} \mathrm{O}_{4} / \mathrm{C}$ hollow sphere via a simple solvothermal route. The resulting composite shows a high specific capacity of $911 \mathrm{mAh} \mathrm{g}^{-1}$ in the initial de-lithiation process and a (for conversion materials) high capacity retention of $91 \%$ after 30 cycles. ${ }^{19}$ Ding et al. adopted a polymer pyrolysis method to synthesize a nanostructured ternary transition metal oxide, $\mathrm{ZnFe}_{2} \mathrm{O}_{4}$, which showed a high specific capacity and good cycling performance. $^{18}$

Hence, considerable efforts have been devoted for the synthesis of $\mathrm{ZnFe}_{2} \mathrm{O}_{4}$ with a variety of nanostructures, such as hollow spheres, ${ }^{35,36}$ octahedrons, ${ }^{37}$ nanofibers ${ }^{38}$ and nanorods. ${ }^{39}$ However, many of these morphologies were fabricated by high temperature or long reaction time methods. The possible synthesis routes for $\mathrm{ZnFe}_{2} \mathrm{O}_{4}$ are reviewed in Table1, including precipitation, ${ }^{40-42}$ hydrothermal/solvothermal ${ }^{35,36}$ refluxing ${ }^{43}$, microemulsion, ${ }^{44}$ polymer pyrolysis ${ }^{45}$ pulsed laser deposition, ${ }^{45}$ molten salt ${ }^{46}$ and sol-gel methods. ${ }^{47,48}$ Among these methods, hydrothermal processing is the most commonly used way to design $\mathrm{ZnFe}_{2} \mathrm{O}_{4}$-based anode materials for LIBs. This is due to its simplicity (easy operation), the possibility for large-scale production and relatively low costs of raw material and equipment.

Ionic liquids (ILs), as a new species of reaction media, have been extensively studied due to their unique properties such as low volatility, low flammability, high thermal stability, designable structures, and high ionic conductivity, and depending on the chemistry, also high chemical and electrochemical stability, etc. ${ }^{49}$ Recently, ILs have proved to be an excellent media for inorganic synthesis and they have attracted increasing attention as templates and/or solvents for the preparation of nanostructured materials. ILs demonstrate tunable solvent properties which make them to easily interact with various surface and chemical reaction environments. Moreover, ILs with hydrophobic regions and high directional polarizability can form extended hydrogen bond systems in the liquid state, resulting in a highly structured self-assembly. ${ }^{50}$

In this work, we report a novel synthesis route, i.e., an ionic liquid-assisted synthesis method, for the preparation of $\mathrm{ZnFe}_{2} \mathrm{O}_{4}$. The obtained material demonstrates a relatively uniform morphology with fine particles which are composed of ca. $50 \mathrm{~nm}$-sized $\mathrm{ZnFe}_{2} \mathrm{O}_{4}$ crystallites. Furthermore, sucrose is employed as carbon source to coat the $\mathrm{ZnFe}_{2} \mathrm{O}_{4}$ with a thin layer so as to enhance the surface electronic conductivity as well as the surface area for use as high-capacity and high-power anode material in LIBs. In addition, studies on the $\mathrm{Fe}$ and $\mathrm{Zn}$ losses of the $\mathrm{ZnFe}_{2} \mathrm{O}_{4}$ active material upon storage and cycling were performed, which can be generally related to (1) active particle losses from the electrode and (2) metal ion dissolution in the electrolyte. In this study, metal ion dissolution of $\mathrm{ZnFe}_{2} \mathrm{O}_{4}$ will be compared to those of other high capacity anode materials including silicon, tin and germanium.

\section{Experimental}

\section{1. Preparation of $\mathrm{Fe}\left(\mathrm{NO}_{3}\right)_{3}$}

$\mathrm{Fe}\left(\mathrm{NO}_{3}\right)_{3} \cdot 9 \mathrm{H}_{2} \mathrm{O}$ (Sigma-Aldrich, purity: $98 \%$ ) was put in a furnace and heated with a rate of $3 \mathrm{~min}^{-1}$ to $140{ }^{\circ} \mathrm{C}$ for 2 hours under argon atmosphere. By this process, the crystal water was removed and $\mathrm{Fe}\left(\mathrm{NO}_{3}\right)_{3}$ was obtained.

\section{2. Preparation of $\mathrm{ZnFe}_{2} \mathrm{O}_{4}$ particles}

A mixture of $5 \mathrm{~mL}$ of 1-butyl-3-methylimidazolium tetrafluoroborate $\left(\mathrm{BMIMBF}_{4}\right.$; Sigma-Aldrich, purity: 98.5\%) and $35 \mathrm{~mL}$ of ethylene alcohol (Sigma-Aldrich, purity: $99.8 \%$ ) was applied as solvent medium. $0.61 \mathrm{~g}$ $\mathrm{Zn}\left(\mathrm{O}_{2} \mathrm{CCH}_{3}\right)_{2}$ (Sigma-Aldrich, purity: 99.99\%) and $2.17 \mathrm{~g} \mathrm{Fe}\left(\mathrm{NO}_{3}\right)_{3}$ were dissolved in the above mentioned solvent by stirring for 24 hours to form a homogeneous solution and then transferred to a $50 \mathrm{~mL}$ sized Teflon-lined autoclave at $150{ }^{\circ} \mathrm{C}$ for 3 hours. The resultant product was collected by centrifugation, alternately washed several times with de-ionized water and ethanol and then dried at $80{ }^{\circ} \mathrm{C}$ in a vacuum oven. The solid product was finally calcined at $500{ }^{\circ} \mathrm{C}$ for 2 hours under argon atmosphere.

\section{3. Preparation of $\mathrm{ZnFe}_{2} \mathrm{O}_{4} /$ carbon Composite}

$0.72 \mathrm{~g}$ sucrose (Sigma-Aldrich, purity: $98.5 \%$ ) was dissolved in $4 \mathrm{~mL}$ of de-ionized water and subsequently 1.0 $\mathrm{g}$ of as-prepared $\mathrm{ZnFe}_{2} \mathrm{O}_{4}$ was added under continuous stirring. The obtained mixture was homogenized using planetary ball milling (Vario-Planetary Mill Pulverisette 4, FRITSCH) set at $800 \mathrm{rpm}$ for 2 hours and subsequently dried at $80{ }^{\circ} \mathrm{C}$ for 12 hours. The dry composite was then heated with a rate of $3 \mathrm{C} \mathrm{min}^{-1}$ to $500{ }^{\circ} \mathrm{C}$ for 4 hours under argon atmosphere. Finally, the obtained powder was grinded manually using an agate mortar for further characterization. The carbon amount of the composite was determined by thermogravimetric analysis (TGA) under oxygen atmosphere. For comparison, commercial $\mathrm{ZnFe}_{2} \mathrm{O}_{4}$ (Sigma-Aldrich, purity: 99\%; hereafter abbreviated as "comm-Zn$\mathrm{Fe}_{2} \mathrm{O}_{4}$ ") was employed to have a comparison with the selfprepared $\mathrm{ZnFe}_{2} \mathrm{O}_{4}$ in the electrochemical investigations. The carbon coating of comm- $\mathrm{ZnFe}_{2} \mathrm{O}_{4} /$ carbon was performed in the same way and the carbon content has been identified to be the same as for the self-prepared material.

\section{4. Structure and Morphology Characterization}

$\mathrm{X}$-ray diffraction (XRD) measurements were carried out using a Bruker D8 Avance X-ray diffractometer (Bruker AXS GmbH) equipped with a copper target X-ray tube (radiation wavelength: $\lambda=0.154 \mathrm{~nm}$ ). The morphology of the samples was observed by a field-emission scanning electron microscope (FESEM, JEOL JSM-7401F). 
Thermogravimetric analysis (TGA) was conducted using a TGA Q5000 IR system (TA Instruments). The measurements were carried out in oxygen atmosphere (oxygen flow: $10 \mathrm{~mL} \mathrm{~min}^{-1}$ ) in the temperature range of $30^{\circ} \mathrm{C}$ to $800{ }^{\circ} \mathrm{C}$ with a heating rate of $10^{\circ} \mathrm{C} \mathrm{min}$.

The BET specific surface area and BJH pore diameter distribution were determined by nitrogen adsorption measurements using an ASAP 2020 (Accelerated Surface Area and Porosimetry Analyzer, Micromeritics $\mathrm{GmbH}$ ). Before the measurement, the samples were degassed at $120{ }^{\circ} \mathrm{C}$ until a static pressure of less than 0.01 Torr (0.0133 mbar) was reached.

\section{5. Electrode Preparation, Cell Assembly and Electrochemical Investigations}

Composite electrodes were prepared using a composition of $80 \mathrm{wt} . \%$ active material, $10 \mathrm{wt}$. $\%$ of conductive carbon black agent C-nergy Super C65 (Imerys Graphite \& Carbon) and $10 \mathrm{wt} . \%$ of sodium-carboxymethyl cellulose (Na-CMC, Walocel CRT 2000 PA 12) as binder. Prior to the dispersion of the solid compounds, the binder polymer was dissolved in de-ionized water to obtain a 2.0 wt.\% solution. An appropriate amount of Super C65 was added to the binder solution and the mixture was further homogenized by stirring. Afterwards, a high-energy dispersion step (Ultra-Turrax T25, 1 hour, 5,000 rpm) was employed to eliminate agglomerates and to homogenize the mixture. The paste was cast on a copper foil by a standard lab-scale doctor-blade technique. The gap of the doctor-blade was set to $120 \mu \mathrm{m}$ wet film thickness, leading to an average mass loading of $1.08 \mathrm{mg} \mathrm{cm}^{-2}$. After casting, the tapes were transferred into an oven and dried in air for 1 hour at $80{ }^{\circ} \mathrm{C}$. Electrodes with a diameter of $12 \mathrm{~mm}$ were cut out and a further drying step was performed under an oil-pump vacuum $(<0.1 \mathrm{mbar})$ at $120{ }^{\circ} \mathrm{C}$ for 24 hours.

Electrochemical experiments were performed using CR2032-type coin cells with Celgard 2400 as separator and high-purity metallic lithium foil (Rockwood Lithium) as counter electrode. The electrolyte (UBE Europe Gmb$\mathrm{H})$ was $1 \mathrm{M} \mathrm{LiPF}_{6}$ in a mixture of ethylene carbonate (EC) and diethyl carbonate (DEC) (3:7 in weight ratio). The cells were assembled in an argon-filled glove box (UniLab, MBraun) with oxygen and water contents of less than $1 \mathrm{ppm}$. The electrochemical performance was evaluated on a Maccor 4300 battery test system at $20{ }^{\circ} \mathrm{C}$. The cut-off voltage was $0.01 \mathrm{~V}$ for the discharge process (= lithiation) and $3.0 \mathrm{~V}$ for the charge process (= de-lithiation). The specific capacity was calculated on the basis of the total composite weight, and the C-rate was calculated with respect to a theoretical capacity of $1,000 \mathrm{mAh} \mathrm{g}^{-1}$ (1C). In the case of the $\mathrm{ZnFe}_{2} \mathrm{O}_{4}$ composite electrode, the theoretical capacity is ca. $940 \mathrm{mAh} \mathrm{g}^{-1}$ (assuming a reversible capacity of ca. $550 \mathrm{mAh} \mathrm{g}^{-1}$ for the pyrolized carbon ${ }^{51}$ ). Cyclic voltammetry (CV; 0.01-3.0 V) was performed with a scan rate of $0.02 \mathrm{mV} \mathrm{s}^{-1}$ using a VMP multichannel constant voltage-constant current system (Bio-Logic Science Instruments).

In situ XRD analysis of the $\mathrm{ZnFe}_{2} \mathrm{O}_{4}$ anode material upon galvanostatic lithiation and de-lithiation was performed by using a self-designed in situ cell, whose design has been inspired by earlier reports. ${ }^{52-54}$ The electrode stack is electronically insulated from the stainless steel body by a sheet of Mylar foil. The electrode paste was cast on a beryllium (Be) window, which served as both the current collector and "window" for the X-ray beam, to analyze the structure changes during the lithiation and de-lithiation processes of $\mathrm{ZnFe}_{2} \mathrm{O}_{4}$. The coated Be window was subsequently dried at $80^{\circ} \mathrm{C}$ for 30 minutes in air and at $40{ }^{\circ} \mathrm{C}$ under vacuum $(<0.1$ mbar $)$ for 12 hours. Metallic lithium foil served as the counter electrode. A Whatman ${ }^{\circledR}$ glass fiber (grade GF/D) served as separator, drenched with $500 \mu \mathrm{L}$ of the electrolyte, $1 \mathrm{M} \mathrm{LiPF}_{6}$ in EC:DEC 3:7 (in weight ratio). The assembled cell was allowed to rest for 6 hours to ensure a sufficient wetting of the electrode. Subsequently, the cell was galvanostatically cycled at a specific charge/discharge current of $0.05 \mathrm{C}$ to a complete initial discharge (= lithiation) to 0.01 $\mathrm{V}$, for approximately 10 hours. In parallel, XRD patterns were acquired in an angular range of 20 to 80, with a step size of 0.02239 and a time per step of 0.4 seconds, resulting in a complete scan for every 20 minutes. After discharging, the cell was charged (= de-lithiation) to an upper cut-off voltage of $3 \mathrm{~V}$.

\section{6. Analytical Studies on Metal Ion Dissolution by Total Reflection X-Ray Fluorescence (TXRF)}

After electrochemical measurements, the separators were separated from the cells and placed in $1.5 \mathrm{~mL}$ Eppendorf reaction vessels. Afterwards, the separator samples were centrifuged at $8500 \mathrm{rpm}$ over 10 minutes using the Galaxy 5D (VWR International Inc.) in order to collect the cycled electrolyte. Thereafter, the electrolyte was diluted 1:10 using a solution containing $1 \mathrm{ppm}$ Germanium $\left(1000 \mathrm{mg} / \mathrm{L}\right.$, Certipur, ${ }^{\circledR}$ Merck) in $2 \mathrm{v} \%$ nitric acid (65 v\%, Suprapur, ${ }^{\circledR}$ Merck) as internal standard for quantification. The dilution of the acid was carried out using deionized water $\left(18.2 \mathrm{~m} \Omega / \mathrm{cm}^{2}, 5 \mathrm{ppb}\right.$ TOC, Millipore Corporation). For analysis, a small portion of $5 \mu \mathrm{L}$ from the diluted electrolyte was transferred onto a pre-siliconized quartz glass carrier (Bruker Corporation) and dried by heat at $55{ }^{\circ} \mathrm{C}$ until the solvent was evaporated. For the Total Reflection X-ray Fluorescence (TXRF) measurements, a Picofox S2 system equipped with the Spectra 7.5 software (Bruker Corporation) was used. The conditions for the measurements were set at 1000 seconds irradiation per sample, in order to obtain sharp signals. The $\mathrm{X}$-rays were generated via a Molybdenum source as anode material at voltages of $50 \mathrm{kV}$ and currents of $600 \mu \mathrm{A}$ leading to exci-

Jia et al.: Nanostructured $\mathrm{ZnFe}_{2} \mathrm{O}_{4}$ as Anode Material ... 
tation energies of $17.5 \mathrm{keV}$. The X-ray fluorescence of the samples was measured using a silicon-drift detector (SDD).

\section{Results and Discussion}

\section{1. Structural Characterization of $\mathrm{ZnFe}_{2} \mathrm{O}_{4}$ and $\mathrm{ZnFe}_{2} \mathrm{O}_{4} /$ carbon}

As schematically illustrated in Figure 2a, the precursors of zinc and iron were dissolved in ethanol, which was accompanied with the formation of M-O bonds. The large cations and anions in 1-butyl-3-methylimidazolium tetrafluoroborate $\left(\mathrm{BMIMBF}_{4}\right)$ could act as self-assembling template, in which the long chain surfactants may hinder an increased aggregation rate of the particles. The proposed formation mechanism of $\mathrm{ZnFe}_{2} \mathrm{O}_{4}$ with the ionic liquid is shown in Figure $2 b$. The formation of the intermediate product corresponds to an effective aggregation of the MO particles with a highly structured self-assembled ionic liquid due to the hydrogen bonding and/or a $\pi-\pi$ stacking mechanism. ${ }^{55}$ After calcination, the desired product of nanostructured $\mathrm{ZnFe}_{2} \mathrm{O}_{4}$ particles can be obtained.

The $\mathrm{ZnFe}_{2} \mathrm{O}_{4}$ phase of the prepared $\mathrm{ZnFe}_{2} \mathrm{O}_{4}$ particles was characterized by powder X-ray diffraction analysis, as shown in Figure 3. The XRD pattern can be indexed to the spinel $\mathrm{ZnFe}_{2} \mathrm{O}_{4}$ phase (space group $F d \overline{3} m$, No. 227, PDF card No. 04-008-5691), ${ }^{56}$ and no impurity phase was observed. Meanwhile, the positions of all peaks are in good agreement with commercial $\mathrm{ZnFe}_{2} \mathrm{O}_{4}$, which means it is feasible to obtain $\mathrm{ZnFe}_{2} \mathrm{O}_{4}$ via an ionic liquid-assisted synthesis method. In the case of the carbon-coated $\mathrm{Zn}$ $\mathrm{Fe}_{2} \mathrm{O}_{4}$ composite, no extra peaks were observed, which means the residual carbon is amorphous.

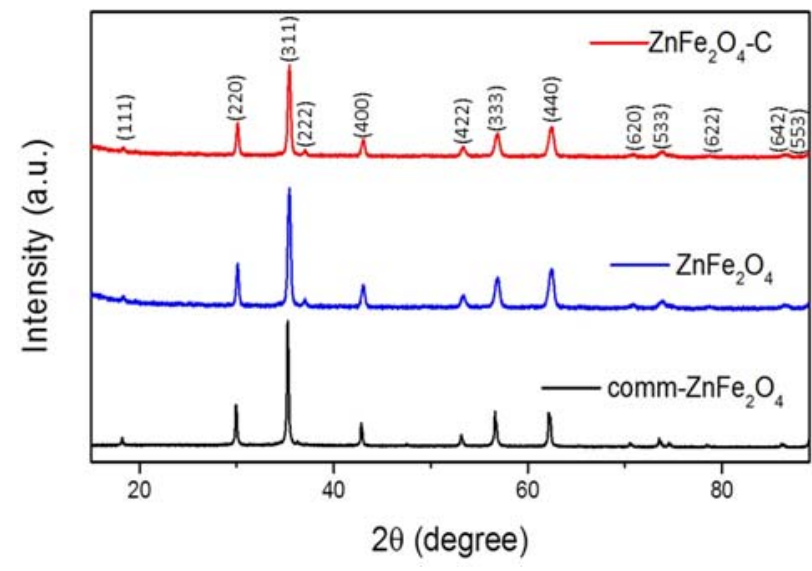

Figure 3. XRD patterns of the self-prepared $\mathrm{ZnFe}_{2} \mathrm{O}_{4}$ and $\mathrm{Zn}$ $\mathrm{Fe}_{2} \mathrm{O}_{4} / \mathrm{C}$ material and of the commercial $\mathrm{ZnFe}_{2} \mathrm{O}_{4}$ particles.

The amount of carbon was determined by thermogravimetric analysis, which was carried out under oxygen atmosphere, as illustrated in Figure 4. The weight loss at the beginning can be attributed to absorbed water. From $100{ }^{\circ} \mathrm{C}$ to $300{ }^{\circ} \mathrm{C}$, there is a small weight increase $(0.7 \mathrm{wt} . \%)$, which most likely means that the surface of the composite reacts with the oxygen, eventually for-

(a) $\mathrm{MX}_{\mathrm{a}}+\mathrm{CH}_{3} \mathrm{CH}_{2} \mathrm{OH} \longrightarrow$<smiles>[M]O[W]([M])(O)O[W]([M])(O)O</smiles>

(b)

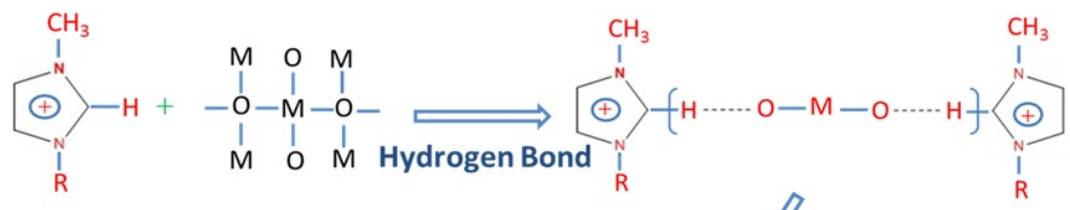

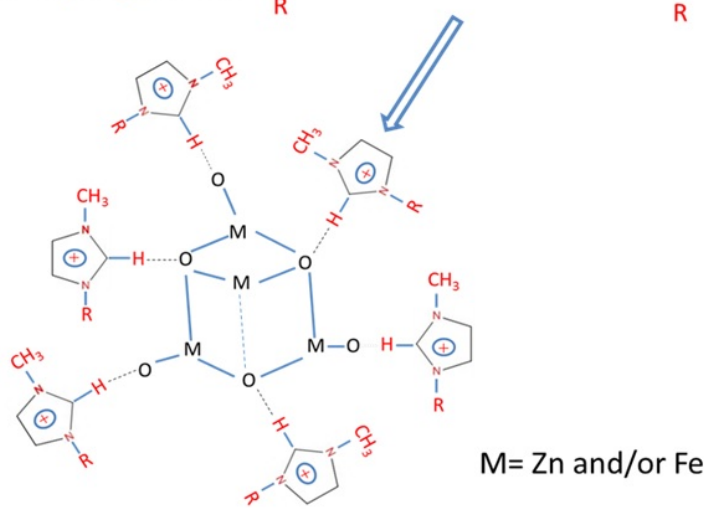

Figure 2. Schematic illustration of the preparation process of the $\mathrm{ZnFe}_{2} \mathrm{O}_{4}$ material $(\mathrm{R}=$ butyl). 


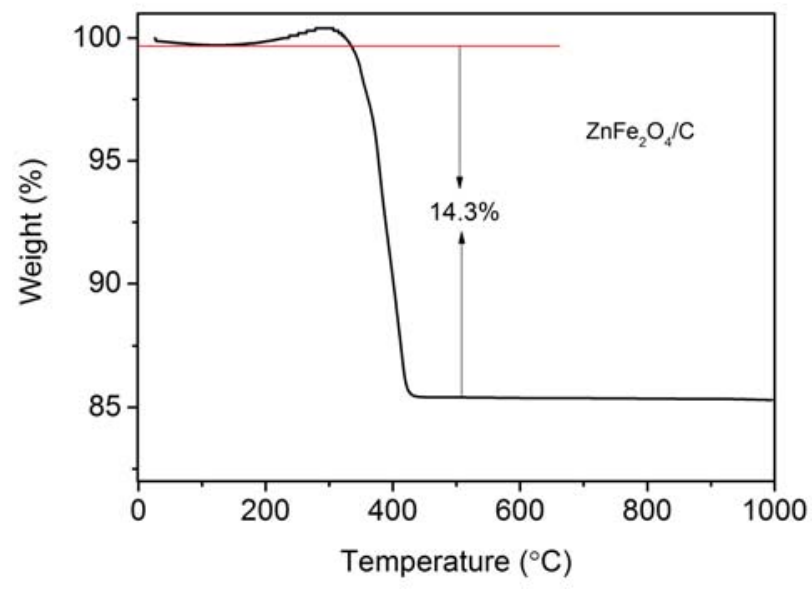

Figure 4. Weight loss curve of the self-prepared $\mathrm{ZnFe}_{2} \mathrm{O}_{4} / \mathrm{C}$ composite material under oxygen atmosphere.

ming carbon-oxygen compounds ${ }^{57}$ The rapid mass loss between $350{ }^{\circ} \mathrm{C}$ and $420^{\circ} \mathrm{C}$ was caused by the oxidation of carbon. Above $420{ }^{\circ} \mathrm{C}$, almost no more weight loss was observed, implying the composites are stable. Thus, the mass percentage of carbon in the composite is calculated to $14.3 \mathrm{wt} \%$.

Figure 5 presents (a) SEM and (b) TEM images of the as-prepared $\mathrm{ZnFe}_{2} \mathrm{O}_{4}$ material. It can be clearly observed that the $\mathrm{ZnFe}_{2} \mathrm{O}_{4}$ particles exhibit a spherical-like morphology with particle sizes ranging from 40 to $100 \mathrm{~nm}$, consisting of an agglomeration of some small particles. Nevertheless, in view of the overall particles, the prepared $\mathrm{ZnFe}_{2} \mathrm{O}_{4}$ material demonstrates a better homogeneity and distribution compared to the commercial $\mathrm{Zn}$ $\mathrm{Fe}_{2} \mathrm{O}_{4}$ (Figure $\mathrm{S} 1$, see the supporting information).

In order to further determine the chemical composition and distribution of $\mathrm{ZnFe}_{2} \mathrm{O}_{4}$, energy dispersive $\mathrm{X}$-ray spectroscopy (EDX) analysis was performed (Figure S2, supporting information). Elemental $\mathrm{Zn}, \mathrm{Fe}$ and $\mathrm{O}$ were detected in the particles, and all the elements are homogeneously distributed. In the case of the commercial $\mathrm{ZnFe}_{2} \mathrm{O}_{4}$ (see Figure $\mathrm{S} 1$ ), primary particles having sizes ranging from 50 to $100 \mathrm{~nm}$ are observed. However, the primary particle demonstrates a strong aggregation tendency,
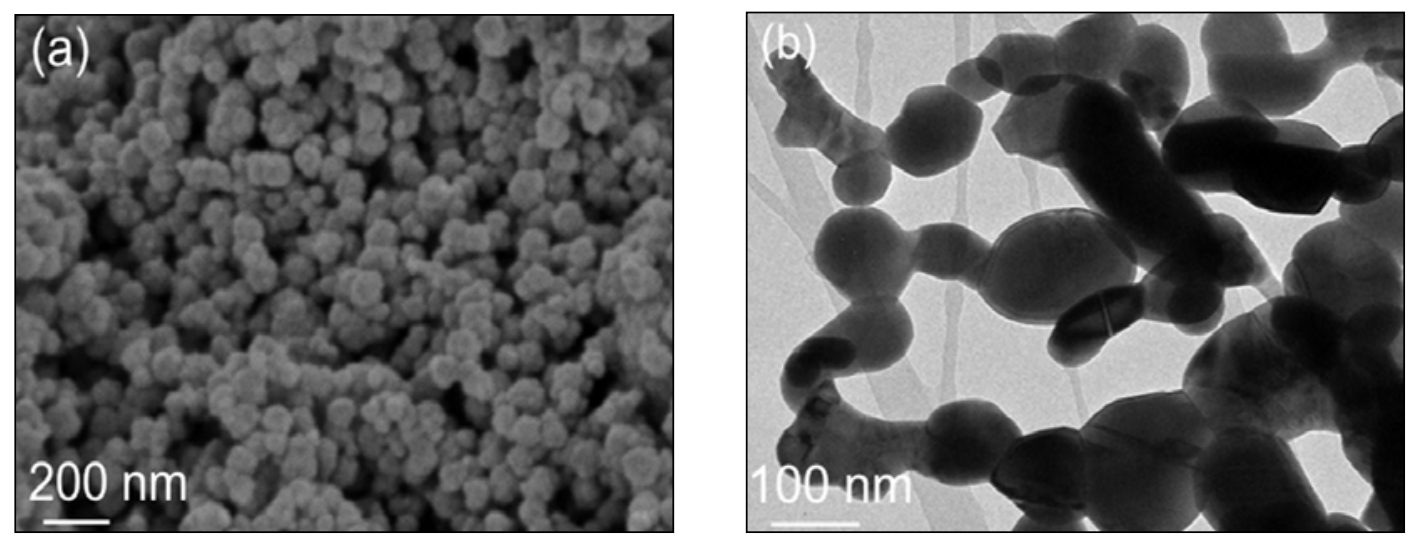

Figure 5. SEM (a) and TEM (b) images of the self-prepared $\mathrm{ZnFe}_{2} \mathrm{O}_{4}$ particles.
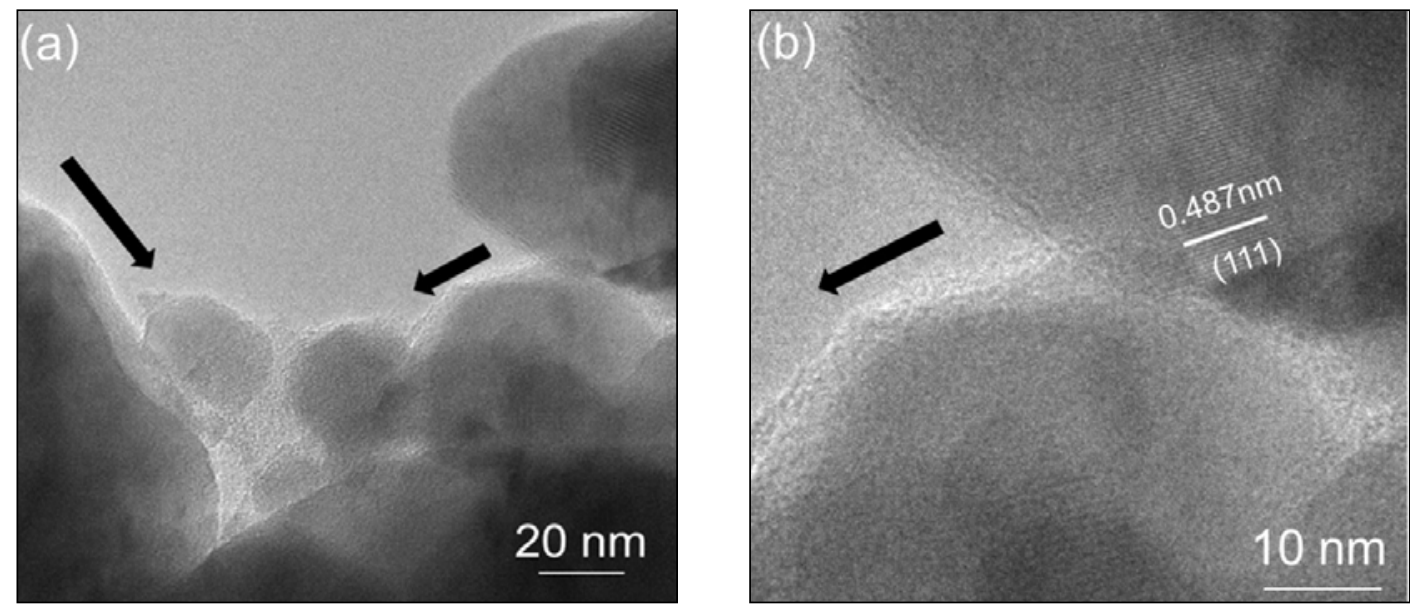

Figure 6. HR-TEM images of the $\mathrm{ZnFe}_{2} \mathrm{O}_{4} / \mathrm{C}$ composite. 
which will result in increased lithium ion diffusion pathways and lead to poor cycling performance and rate capability.

The conducting surface layer on the poor-conducting active materials often plays an important role on the cycling stability and fast charge-discharge properties. Hence, sucrose was used as carbon source to acquire the carbon coated $\mathrm{ZnFe}_{2} \mathrm{O}_{4}$ composite (hereafter abbreviated as $\mathrm{ZnFe}_{2} \mathrm{O}_{4} / \mathrm{C}$ ) with the carbon content of $14.3 \mathrm{wt} . \%$. Figure 6 reveals that the carbon layer, covering the surface of $\mathrm{ZnFe}_{2} \mathrm{O}_{4}$ particles, is about $8 \mathrm{~nm}$ in thickness. One can also clearly see the lattice fringes with an interplanar spacing of $0.487 \mathrm{~nm}$, corresponding to the $\mathrm{ZnFe}_{2} \mathrm{O}_{4}(111)$ plane.

In addition, the BET specific surface area of the prepared $\mathrm{ZnFe}_{2} \mathrm{O}_{4}$ and the corresponding $\mathrm{ZnFe}_{2} \mathrm{O}_{4} / \mathrm{C}$ composite were measured to be $23.8 \mathrm{~m}^{2} \mathrm{~g}^{-1}$ and $112.3 \mathrm{~m}^{2} \mathrm{~g}^{-1}$, respectively. With regard to commercial $\mathrm{ZnFe}_{2} \mathrm{O}_{4}$ and carbon-coated $\mathrm{ZnFe}_{2} \mathrm{O}_{4}$, the values are $18.6 \mathrm{~m}^{2} \mathrm{~g}^{-1}$ and $82.4 \mathrm{~m}^{2} \mathrm{~g}^{-1}$, respectively. The increase in the BET surface area can be attributed to the amorphous carbon-coating surrounding the $\mathrm{ZnFe}_{2} \mathrm{O}_{4}$ particles. ${ }^{58,59}$ The porous and conductive carbon layer is intended to increase the electronic conductivity as well as to offer an easy electrolyte access to the particles, thus resulting in the improvement of the electrochemical performance.

\section{2. Electrochemical Lithiation and de-lithiation of $\mathrm{ZnFe}_{2} \mathrm{O}_{4} /$ carbon}

Figure 7a displays representative voltage profiles for the discharge/charge cycling of $\mathrm{ZnFe}_{2} \mathrm{O}_{4} / \mathrm{C}$ electrodes at a rate of $0.1 \mathrm{C}$ in the first cycle (formation cycle) and $0.5 \mathrm{C}$ in the following cycles, within the voltage range of $0.01 \mathrm{~V}$ to $3 \mathrm{~V}$. The first de-lithiation and lithiation capacities are $995 \mathrm{mAh} \mathrm{g}^{-1}$ and $1,327 \mathrm{mAh} \mathrm{g}^{-1}$, respectively, with an initial Coulombic efficiency of $75 \%$. The first irreversible capacity can be attributed to the decomposition of electrolyte to form the solid electrolyte interphase (SEI) on the electrode surface..$^{34,40,60}$ As for many other conversion materials, the discharge curve spans over a wide potential range, in this case $3 \mathrm{~V}$, with a medium de-lithiation potential of $1.7 \mathrm{~V}$ vs. $\mathrm{Li} / \mathrm{Li}^{+}$(at $1 \mathrm{C}$ ), affecting the available energy content in a full cell. In addition, there is a large hysteresis, which will affect the energy efficiency. These effects will be discussed in detail below.

The electrochemical lithiation/de-lithiation characteristics of the $\mathrm{ZnFe}_{2} \mathrm{O}_{4}$ material were further determined using cyclic voltammetry (CV), as shown in Figure 7b. Upon the initial cathodic sweep, a small peak can be observed at around $0.9 \mathrm{~V}$ (section $\mathrm{B}$ ), followed by a main sharp reduction peak at around $0.7 \mathrm{~V}$ (section $\mathrm{C}$ ). It is proposed that $\mathrm{ZnFe}_{2} \mathrm{O}_{4}$ could be initially lithiated to $\mathrm{Li}_{0.2} \mathrm{ZnFe}_{2} \mathrm{O}_{4}$ or $\mathrm{Li}_{0.5} \mathrm{ZnFeO}_{4}$ and $\mathrm{Li}_{2} \mathrm{ZnFe}_{2} \mathrm{O}_{4}$, subsequently reduced to $\mathrm{Li}-$ $\mathrm{Zn}, \mathrm{Fe}^{0}$, and $\mathrm{Li}_{2} \mathrm{O} .{ }^{20,61,62}$ For the first charge process (= delithiation), one broad oxidation peak around 1.6 to $1.7 \mathrm{~V}$
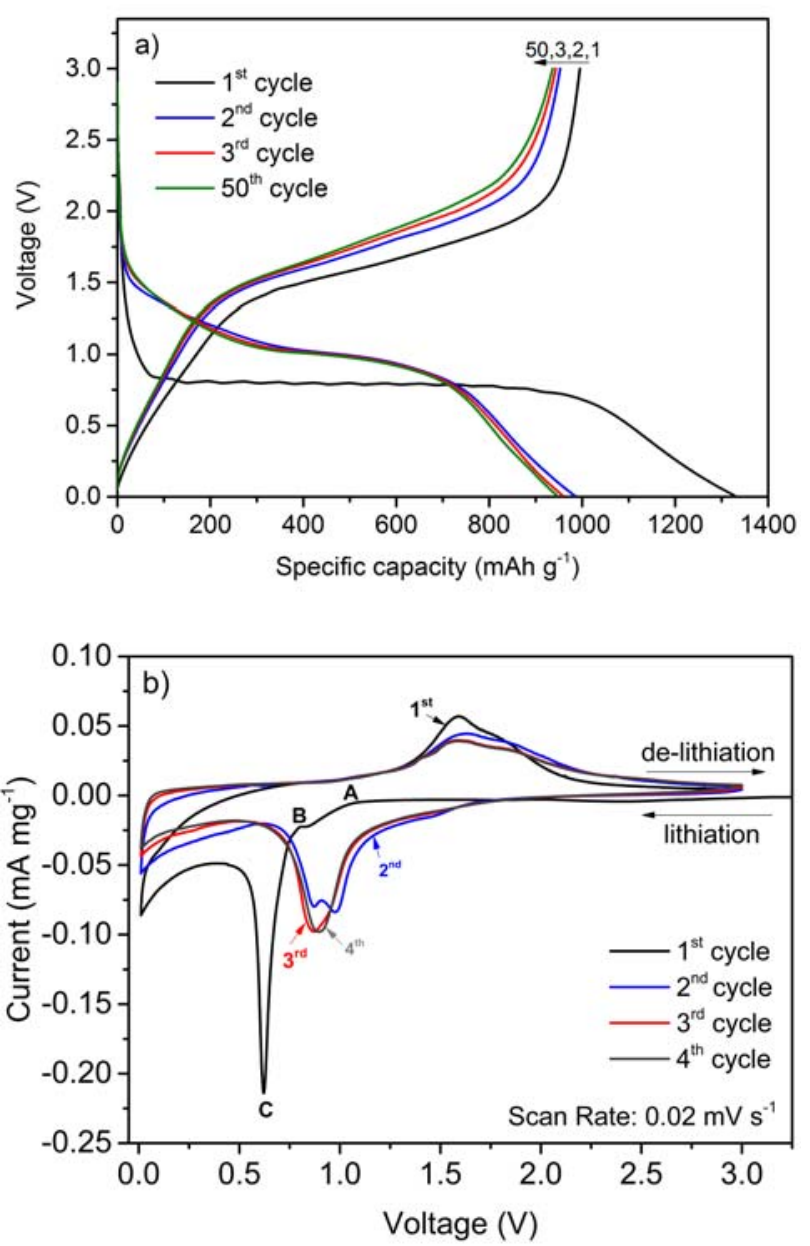

Figure 7. a) Representative voltage vs. specific capacity profiles of the constant current charge/discharge cycling of $\mathrm{ZnFe}_{2} \mathrm{O}_{4} / \mathrm{C}$ at $0.1 \mathrm{C}$ $\left(1^{\text {st }}\right.$ cycle $)$ and $0.5 \mathrm{C}\left(2^{\text {nd }}\right.$ cycle; $3^{\text {rd }}$ cycle and $50^{\text {th }}$ cycle $\left.) ; b\right)$ Cyclic voltammetry investigation of the electrode at a scan rate of $0.02 \mathrm{~m}$ $\mathrm{V} \mathrm{s}^{-1}$ displaying cycles $1-4$. Voltage limits: $0.01 \mathrm{~V}$ and $3 \mathrm{~V}$.

and a shoulder at a higher voltage are observed. In case of the second cathodic scan, the peaks are shifted to a higher voltage and separated into two peaks at around 0.8 and $1.0 \mathrm{~V}$, indicating that the reduction proceeds by a two-step process, while the two broad corresponding anodic peaks appear at 1.6 and $1.9 \mathrm{~V}$. Subsequent scans ( $3^{\text {rd }}$ and in particular the $4^{\text {th }}$ cycle) show most likely only one reduction peak, which is slightly shifted to lower potentials upon continuous sweeps, and two oxidation peaks, associated with two different oxidation reactions (Figure 7b).

In order to investigate the initial electrochemical reaction of $\mathrm{ZnFe}_{2} \mathrm{O}_{4}$ with lithium, in situ XRD analysis coupled with galvanostatic lithiation and de-lithiation has been carried out. Figure 8a displays the in situ XRD patterns, while Figure 8e depicts the corresponding voltage profile of the first electrochemical alloying and de-alloying reaction. For clarity reasons, a more detailed presentation of different scans in the $2 \theta$ range from 61 to 63 is given in Figures $7 \mathrm{~b}-\mathrm{d}$. The numbers of Figure $8 \mathrm{e}$ correspond to the 
XRD scan numbers and can be correlated to those in Figure $8 \mathrm{c}$ and $\mathrm{d}$. The voltage profile illustrated in Figure $8 \mathrm{e}$ can be split in three different sections: A, B and C in analogy to the cyclic voltammetry experiment (Figure 8b). As typically occurring during the first discharge (= lithiation process), the voltage rapidly dropped to below $1.0 \mathrm{~V}$. Afterwards, several processes were found to take place concurrently. Within section $\mathrm{A}$, it is assumed that the XRD patterns acquired in this voltage region (scan 1 to 3 in Figure $8 b)$ reveal a shift of the peak to lower $2 \theta$ values, indicating an increase of the lattice parameters due to the expansion of the $\mathrm{ZnFe}_{2} \mathrm{O}_{4}$ host lattice caused by the uptake of lithium within the spinel structure and the concomitant displacement of the $\mathrm{Zn}^{2+}$ ions into the octahedral $16 \mathrm{c}$ sites. ${ }^{63}$ This expansion is in good agreement with the JCPDS reference 00-040-116 for $\mathrm{Li}_{0.5} \mathrm{ZnFe}_{2} \mathrm{O}_{4}$. However, only a slight shift of the peak is detected in this work, which is even within the error range. Thus, no clear statement can be made. In case of the scans 4 to 17 , the intensity of the peak at $62.4^{\circ}$ decreases and eventually disappears in scan 17 (Figure 8c). At the same time, a new XRD peak is observed at $61.7^{\circ}$, indicating a phase change of the lithiated sample. Thackeray et al. reported the formation of $\mathrm{Li}_{1.5} \mathrm{Fe}_{3} \mathrm{O}_{4}$, obtained during lithium insertion in $\mathrm{Fe}_{3} \mathrm{O}_{4}$, which is an intermediate between spinel and rock-salt. ${ }^{63}$ This agrees very well with the present result of a phase transition from spinel to rock-
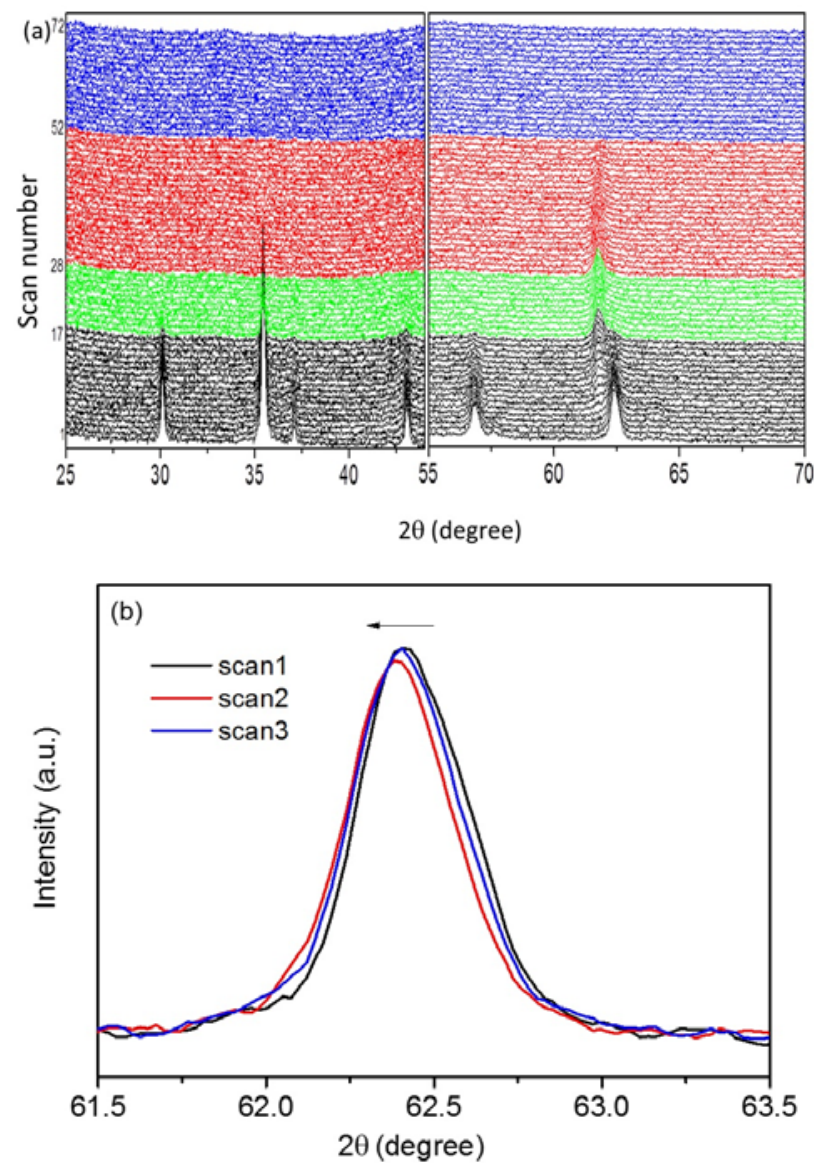
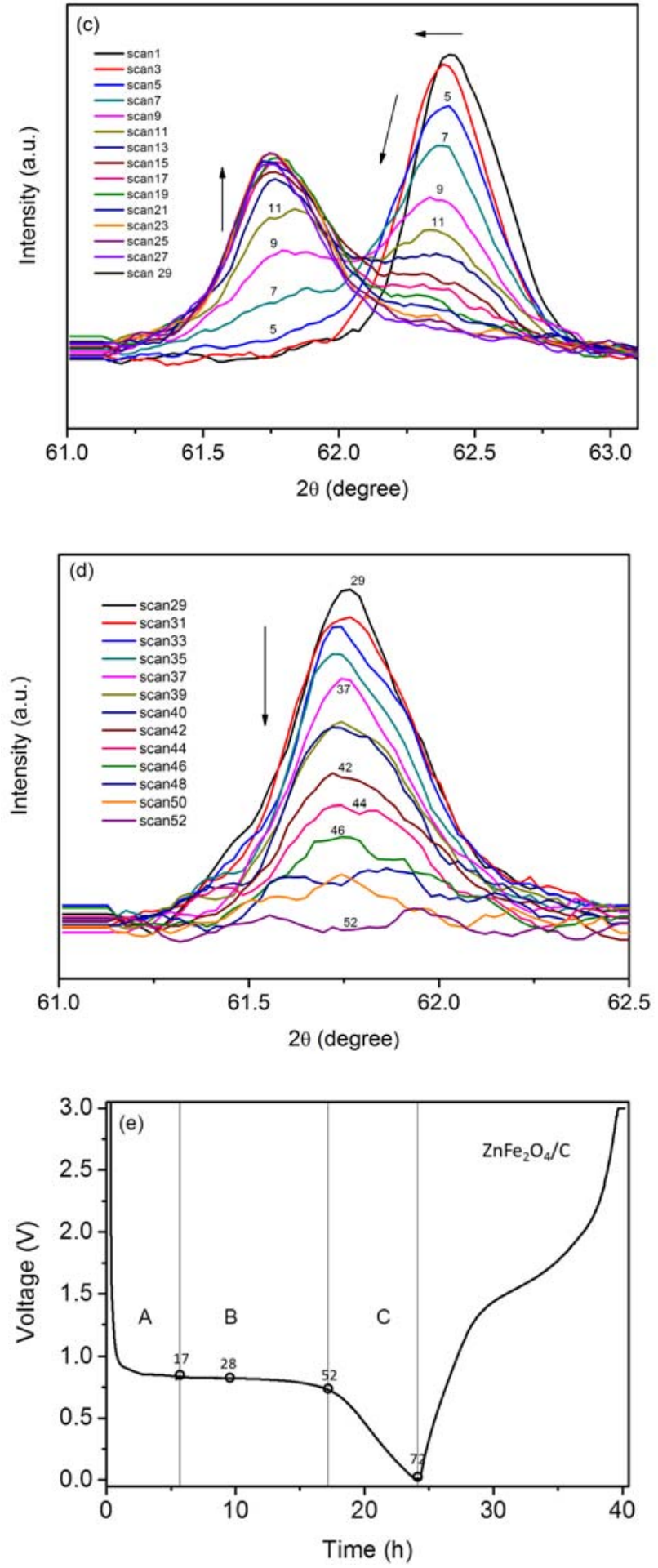

Figure 8. (a) In situ XRD study: Evolution of the XRD patterns upon the first lithiation process (scan 1 to 72). The scans refer to the different sections marked in panel e are indicated by different colors: (A) black, (B) red $\&$ green and (C) blue. The $2 \theta$ ranges from 25 to 45 and 55 to 70 , within which the reflections of the Be window are not shown. Details on the evolution of the XRD patterns: b) Scans 1 to 3; c) Scans 1 to 29 ; d) Scans 29 to 52 (only every cycle second cycle is shown) upon lithiation in a $2 \theta$ range of $61^{\circ}$ to $63^{\circ}$. (e) Representative voltage vs. specific capacity profile of the constant current discharge/charge cycling of the $\mathrm{ZnFe}_{2} \mathrm{O}_{4} / \mathrm{C}$ anode at $0.05 \mathrm{C}\left(1^{\text {st }}\right.$ cycle) belonging to the in situ XRD measurement and displaying corresponding XRD scans. 
salt for $\mathrm{Li}_{x} \mathrm{ZnFe}_{2} \mathrm{O}_{4}$. Bresser et al. proposed that the partially lithiated $\mathrm{Li}_{\mathrm{x}} \mathrm{ZnFe}_{2} \mathrm{O}_{4}$ was decomposed to $\mathrm{Li}_{2} \mathrm{O}$ and a new rock-salt phase of metal oxide, in which all the iron was reduced to $\mathrm{Fe}^{2+} \cdot{ }^{20}$ Upon further lithiation within the main potential plateau (section B in Figure 8e), the newly formed phase shows its highest peak intensity at scan 29 . Subsequently, the intensity of the peak decreased with discharge depth, and it completely disappears at scan 52 (at the end of the long plateau), which indicates the complete decomposition to $\mathrm{Zn}^{0}, \mathrm{Fe}^{0}$, and $\mathrm{Li}_{2} \mathrm{O}$ (Figure 8d). In case of the final section $\mathrm{C}$ (from scan 52 to 72), no XRD features indexed to the particles of $\mathrm{Zn}$ and $\mathrm{Li}-\mathrm{Zn}$ alloy, which is known to generate during this potential region, ${ }^{30,32,34,64}$ could be detected. Thus, we also have faith in the assumption that the fully lithiated phase consisting of $\mathrm{LiZn}$ and $\mathrm{Fe}^{0}$ in an amorphous $\mathrm{Li}_{2} \mathrm{O}$ matrix is most likely to be amorphous. In conclusion, the first lithiation reaction can be described by equation (1).

$$
\begin{aligned}
& \mathrm{ZnFe}_{2} \mathrm{O}_{4}+9 \mathrm{Li}^{+}+9 \mathrm{e}^{-} \rightarrow \mathrm{LiZn}+2 \mathrm{Fe}^{0}+ \\
& +4 \mathrm{Li}_{2} \mathrm{O}
\end{aligned}
$$

The charge/discharge cycling curves and Coulombic efficiency curves of the $\mathrm{ZnFe}_{2} \mathrm{O}_{4} / \mathrm{C}$ composite as well as
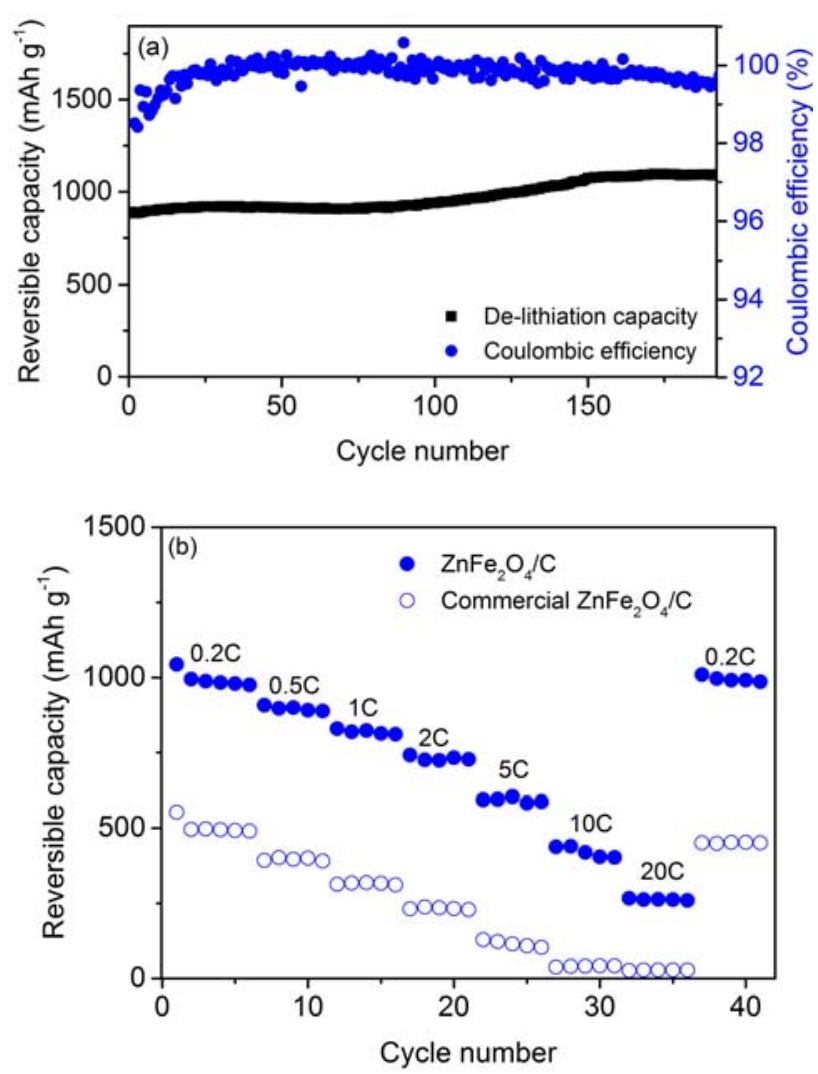

Figure 9. a) De-lithiation capacity curves and coulombic efficiency curves of the constant current cycling of $\mathrm{ZnFe}_{2} \mathrm{O}_{4} / \mathrm{C}$ at $0.1 \mathrm{C} \mathrm{(} 1^{\text {st }}$ cycle) and $0.5 \mathrm{C}$ (following cycles); b) Reversible capacity curves of $\mathrm{ZnFe}_{2} \mathrm{O}_{4} / \mathrm{C}$ at different specific currents (C-rate investigation). Cutoff voltages for a) and b): $0.01 \mathrm{~V}$ and $3.0 \mathrm{~V}$. the rate performance of both the commercial $\mathrm{ZnFe}_{2} \mathrm{O}_{4} / \mathrm{C}$ and self-prepared $\mathrm{ZnFe}_{2} \mathrm{O}_{4} / \mathrm{C}$ composites are illustrated in Figure 9a and b, respectively. The $\mathrm{ZnFe}_{2} \mathrm{O}_{4} / \mathrm{C}$ composite shows a superior cycling stability with a high reversible capacity, even up to 190 cycles, followed by slight capacity increase process upon continuous cycling of the electrode, finally stabilizing at around $1,091 \mathrm{mAh} \mathrm{g}^{-1}$. A similar behavior (gaining extra capacity) was also presented for other transition metal oxides ${ }^{65,66}$ to be associated with the (partially) reversible formation of a polymeric layer on the particles surface. ${ }^{20}$ The excellent cycling stability of $\mathrm{ZnFe}_{2} \mathrm{O}_{4}$ benefits from its structure, which offers an interesting combination of alloying and conversion mechanisms, and the carbon layer.

In particular, the prepared $\mathrm{ZnFe}_{2} \mathrm{O}_{4} / \mathrm{C}$ composite electrode exhibits a superior rate performance, compared to the commercial $\mathrm{ZnFe}_{2} \mathrm{O}_{4} / \mathrm{C}$. As displayed in the charge/discharge rate performance investigation in Figure 9b, the reversible capacity decreases from $1,043 \mathrm{mAh} \mathrm{g}^{-1}$ to $216 \mathrm{mAh} \mathrm{g}^{-1}$, when the charge/discharge rate increases in steps from $0.2 \mathrm{C}$ to $20 \mathrm{C}$. When the rate finally returns to $0.2 \mathrm{C}$, a capacity of $1,008 \mathrm{mAh} \mathrm{g}^{-1}$ can be recovered. In contrast, the commercial $\mathrm{ZnFe}_{2} \mathrm{O}_{4} / \mathrm{C}$ electrode demonstrates lower capacity as well as a dramatic decrease in capacity at high specific currents.

\section{3. Study on Metal Ion Dissolution in the Electrolyte From $\mathrm{ZnFe}_{2} \mathrm{O}_{4}$ /carbon Electrode and Comparison to Other}

\section{Anode Active Materials}

In general, the mass loss of metals from the electrode and/or active material can be most likely related to two contributions: 1) the active material particles lost contact from the composite electrode during the cycling, e.g. due to an enhanced volume expansion/shrinkage, whereby the detached metal particles can be mainly found close to the separator; 2) metal ions dissolved in the electrolyte, similar to metal dissolution from other conversion materials ${ }^{67}$ and to metal ion dissolution from LIB cathode materials. ${ }^{68-70}$

In this work, only the latter degradation mechanism, i.e. the metal ion dissolution in the organic solvent-based electrolyte, is studied. Iron and zinc dissolution from $\mathrm{Zn}$ $\mathrm{Fe}_{2} \mathrm{O}_{4}$ electrodes during the repeated lithiation/de-lithiation process was confirmed by TXRF studies (see Table 2). The uncycled electrodes (storage for 5 days at $20 \mathrm{C}$ ) presented a minor dissolution from the electrodes, i.e. $0.0020 \% \mathrm{Fe}$ loss and $0.0110 \% \mathrm{Zn}$ loss, related to the active masses of iron and zinc in the sample. In case of cycled electrodes (up to 100 cycles), iron exhibits a slightly increasing metal ion dissolution of up to $0.0049 \%$ after 100 cycles, while the zinc content after cycling is even lower than during storage. Overall, both zinc and iron display only minor metal dissolution from $\mathrm{ZnFe}_{2} \mathrm{O}_{4} /$ carbon electrodes in comparison to $\mathrm{Mn}$, $\mathrm{Ni}$ or Co dissolution from cathode materials such as $\mathrm{LiNi}_{0.33} \mathrm{Mn}_{0.33} \mathrm{Co}_{0.33} \mathrm{O}_{2}$. 
Table 2. $\mathrm{Zn}$ and Fe contents (ppm) by metal dissolution in the electrolyte (EC:DEC (3:7), $1 \mathrm{M} \mathrm{LiPF}_{6}$ ) after cycling or storage of $\mathrm{ZnFe}_{2} \mathrm{O}_{4} / \mathrm{C}$ electrodes, detected by the TXRF method. Fe and $\mathrm{Zn}$ losses (\%) are related to the sample weight. electrolyte solution: $100 \mu \mathrm{L} ; \mathrm{active}$ mateial of $\mathrm{ZnFe}_{2} \mathrm{O}_{4}$ : $1.55 \mathrm{mg} \mathrm{cm}^{-2}$, the error for the active material $\left(\mathrm{ZnFe}_{2} \mathrm{O}_{4}\right)$ is $0.02 \mathrm{mg} \mathrm{cm}$.

\begin{tabular}{ccccc}
\hline $\begin{array}{c}\text { Cycling/storage } \\
\text { conditions }\left(\mathbf{a t ~ 2 0}{ }^{\circ} \mathbf{C}\right)\end{array}$ & Fe Content $(\mathbf{p p m})$ & Zn content $(\mathbf{p p m})$ & Fe losses from anode $(\%)$ & Zn losses from anode $(\%)$ \\
\hline Storage for 5 days & $0.35 \pm 0.04$ & $1.90 \pm 0.03$ & $0.0020 \pm 0.0003$ & $0.0110 \pm 0.0002$ \\
$1^{\text {st }}$ cycle & $0.39 \pm 0.06$ & $0.14 \pm 0.03$ & $0.0022 \pm 0.0004$ & $0.0008 \pm 0.0002$ \\
$10^{\text {th }}$ cycle & $0.41 \pm 0.06$ & - & $0.0024 \pm 0.0004$ & - \\
$50^{\text {th }}$ cycle & $0.22 \pm 0.04$ & $0.06 \pm 0.02$ & $0.0013 \pm 0.0003$ & $0.0004 \pm 0.0002$ \\
$100^{\text {th }}$ cycle & $0.85 \pm 0.05$ & $0.05 \pm 0.03$ & $0.0049 \pm 0.0003$ & $0.0003 \pm 0.0002$ \\
\hline
\end{tabular}

From our studies, there are major differences for the metal ion dissolution in the electrolyte for different highcapacity anode materials, such as $\mathrm{Si}, \mathrm{Sn}$ and $\mathrm{Ge}$. While silicon does not show dissolution at all, tin and germanium can be found to a certain amount in the electrolyte (see Tables 3 and 4; for experimental details about the materials and electrode composition see supporting information). Ge exhibits a loss of $0.0017 \%$ after storage for 5 days, which increases to $0.0142 \%$ Ge loss after 100 cycles (Table 2). For the tin-based electrodes, the metal dissolution is even higher, i.e. $0.0053 \% \mathrm{Sn}$ loss after 5 days of storage and even $0.4200 \%$ Sn loss after 100 cycles (Table 3 ). Therefore, the metal ion dissolution of Sn-based electrodes is in the same order of magnitude as for $\mathrm{Mn}, \mathrm{Ni}$ or Co dissolution from e.g. $\mathrm{LiNi}_{0.33} \mathrm{Mn}_{0.33} \mathrm{Co}_{0.33} \mathrm{O}_{2}$-based cat-

Table 3. Sn content by metal dissolution in the electrolyte (EC:DEC (3:7), 1M LiPF ${ }_{6}$ ) after cycling or storage of Sn-based electrodes, detected by the TXRF method. Fe and Zn losses (\%) are related to the sample weight. electrolyte solution: $100 \mu \mathrm{L}$; active material of Sn: $1.32 \mathrm{mg} \mathrm{cm}^{-2}$, the error for the active material (Sn) is $0.02 \mathrm{mg} \mathrm{cm}^{-2}$.

\begin{tabular}{ccc}
\hline $\left.\begin{array}{c}\text { Cycling/storage } \\
\text { conditions }(\mathbf{a t} \mathbf{2 0}\end{array}{ }^{\circ} \mathbf{C}\right)$ & $\begin{array}{c}\text { Sn Content } \\
(\mathbf{p p m})\end{array}$ & $\begin{array}{c}\text { Sn losses from anode } \\
(\mathbf{\%})\end{array}$ \\
\hline Storage for 5 days & $0.80 \pm 0.02$ & $0.0053 \pm 0.0002$ \\
$1^{\text {st }}$ cycle & $8.16 \pm 0.63$ & $0.0547 \pm 0.0043$ \\
$10^{\text {th }}$ cycle & $16.25 \pm 0.74$ & $0.1091 \pm 0.0049$ \\
$50^{\text {th }}$ cycle & $32.16 \pm 0.82$ & $0.2100 \pm 0.0055$ \\
$100^{\text {th }}$ cycle & $61.37 \pm 0.93$ & $0.4200 \pm 0.0062$ \\
\hline
\end{tabular}

Table 4. Ge content by metal dissolution in the electrolyte (EC:DEC (3:7), 1M LiPF ${ }_{6}$ ) after cycling or storage of Ge electrodes, detected by the TXRF method. Fe and Zn losses (\%) are related to the sample weight. electrolyte solution: $100 \mu \mathrm{L}$; active material of Ge: $1.51 \mathrm{mg} \mathrm{cm}^{-2}$; the error for the active material $(\mathrm{Ge})$ is $0.02 \mathrm{mg} \mathrm{cm}^{-2}$.

\begin{tabular}{ccc}
\hline $\begin{array}{c}\text { Cycling/storage } \\
\text { conditions }\left(\mathbf{a t ~ 2 0}{ }^{\circ} \mathbf{C}\right)\end{array}$ & $\begin{array}{c}\text { Ge Content } \\
(\mathbf{p p m})\end{array}$ & $\begin{array}{c}\text { Ge losses from anode } \\
(\mathbf{\%})\end{array}$ \\
\hline Storage for 5 days & $0.30 \pm 0.02$ & $0.0017 \pm 0.0002$ \\
$1^{\text {st }}$ cycle & $1.02 \pm 0.02$ & $0.0060 \pm 0.0002$ \\
$10^{\text {th }}$ cycle & $1.51 \pm 0.02$ & $0.0090 \pm 0.0002$ \\
$50^{\text {th }}$ cycle & $1.90 \pm 0.02$ & $0.0112 \pm 0.0002$ \\
$100^{\text {th }}$ cycle & $2.42 \pm 0.03$ & $0.0142 \pm 0.0002$ \\
\hline
\end{tabular}

hode materials. ${ }^{70}$ However, it has to be kept in mind that metal ion dissolution from the cathode strongly depends on the upper cut-off potential. ${ }^{69}$

In summary, the metal ion dissolution from certain anode active materials, including $\mathrm{Sn}, \mathrm{Ge}$ and $\mathrm{ZnFe}_{2} \mathrm{O}_{4}$, should not be underestimated and may have an impact on the overall cell performance and cycling stability. In general, there are several factors which may influence the metal ion dissolution behavior, i.e. the active material properties (particle size, specific surface area, carbon surface coating) and the electrochemical cycling conditions (type of electrolyte, operation potential range, operation temperature, etc.). In case of $\mathrm{ZnFe}_{2} \mathrm{O}_{4}$, the carbon coating may effectively hinder the metal ion dissolution, while for the $\mathrm{Ge}$ and Sn based materials, where no carbon coating was applied, the metal ion dissolution may be enhanced. Further investigations are needed to study systematically the influence of metal ion dissolution on the electrochemical behavior, i.e. to find a correlation to capacity fading and impedance increase.

\section{Conclusion}

In summary, $\mathrm{ZnFe}_{2} \mathrm{O}_{4}$ nanoparticles were successfully prepared using a novel ionic liquid-assisted synthesis method. The obtained material demonstrated a homogenous distribution of $\mathrm{ZnFe}_{2} \mathrm{O}_{4}$ particles, ranging from 40 to $80 \mathrm{~nm}$ in particle diameter. After carbon coating, the resulting $\mathrm{ZnFe}_{2} \mathrm{O}_{4} / \mathrm{C}$ composite displayed a stable capacity of ca. 1,091 mAh g-1 for 190 cycles at $1 \mathrm{C}$ and a high rate capability up to $20 \mathrm{C}$. The great electrochemical performance can be ascribed to the relatively uniform distributed particles, the large BET surface area after carbon coating and highly conductive carbon layer. However, it has to be kept in mind that conversion materials like $\mathrm{ZnFe}_{2} \mathrm{O}_{4}$ suffer from a large irreversible capacity in the first cycle which is in turn related to a large loss of active lithium from the cathode. Moreover, it has to be considered that $\mathrm{ZnFe}_{2} \mathrm{O}_{4}$, as like other conversion-type anode materials, displays a relatively poor energy efficiency, which is related to the large voltage hysteresis, i.e. the difference between the lithiation and de-lithiation potential, which also occurs to a lower extent in insertion electrodes. ${ }^{71}$ Figure 
10 exemplarily displays the potential vs. capacity (normalized) profiles of the different anode materials, i.e. graphitic carbon, silicon/graphite composite and the $\mathrm{ZnFe}_{2} \mathrm{O}_{4} / \mathrm{C}$ composite material. Here, it can be clearly seen that the voltage hysteresis increases from graphite (intercalation mechanism) over Si/C (alloying/intercalation mechanisms) to $\mathrm{ZnFe}_{2} \mathrm{O}_{4} / \mathrm{C}$ (conversion and "alloying" mechanism together with intercalaton into carbon). Considering that this hysteresis (especially at higher C-rates) will result in significant losses of charge energy and in turn these losses are to a large extent equivalent to heat losses, that heat up the cell and thus will damage heat- sensitive cell components such as the electrolyte, it is questionable, whether conversion electrode materials and other electrode materials with large differences in the charge and discharge potentials will have a relevance in batteries. Future research for conversion materials, like $\mathrm{ZnFe}_{2} \mathrm{O}_{4}$, should focus on the topic how to lift the potential of the lithiation process and lower the potential of de-lithiation reaction and thus to increase the energy efficiency.

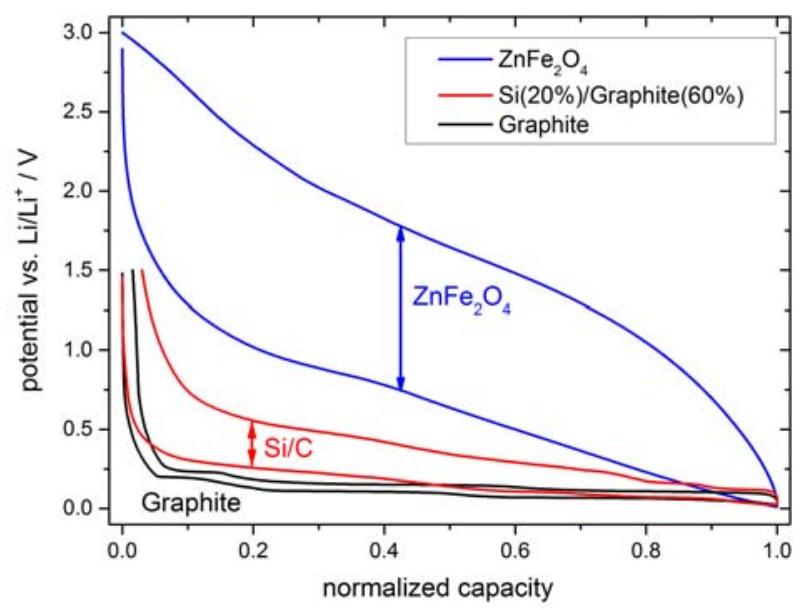

Figure 10. Potential vs. normalized capacity profiles of different anode materials: $\mathrm{ZnFe}_{2} \mathrm{O}_{4} / \mathrm{C}(0.1 \mathrm{C})$, Si/graphite $(0.1 \mathrm{C})$ and graphite $(0.1 \mathrm{C})$.

Studies on the $\mathrm{Zn}$ and $\mathrm{Fe}$ metal ion dissolution process in the electrolyte upon storage and cycling revealed only minor dissolution for both $\mathrm{Zn}$ and $\mathrm{Fe}$ with increasing cycle number in comparison to $\mathrm{Mn}, \mathrm{Ni}$ or $\mathrm{Co}$ dissolution from cathode materials such as $\mathrm{LiNi}_{0.33}$ $\mathrm{Mn}_{0.33} \mathrm{Co}_{0.33} \mathrm{O}_{2}$. However, metal ion dissolution cannot be underestimated and may depend on several active material characteristics such as the particle properties or the carbon coation layer, as well as different electrochemical characteristics such as the type of electrolyte or the cycling conditions. All these factors can influence the metal ion dissolution and, in turn, the electrochemical performance, i.e. the cycling stability and capacity fading. Furthermore, we could show that metal ion dissolution is even more distinct for $\mathrm{Sn}$ - and Ge-based anode materials. The metal dissolution of Sn-based electrodes is even in the same order of magnitude as for metal ion dissolution ( $\mathrm{Mn}, \mathrm{Ni}, \mathrm{Co}$ ) from cathode materials like $\mathrm{LiNi}_{0.33} \mathrm{Mn}_{0.33}$ $\mathrm{Co}_{0.33} \mathrm{O}_{2}$. A systematic study is necessary in order to find a clear correlation between metal ion dissolution vs. capacity fading and impedance increase.

\section{Acknowledgements}

The authors wish to thank the German Research Foundation for funding this work in the project $»$ WeNDeLIB « (Priority Programme 1473; Materials with New Design for Improved Lithium Ion Batteries). The authors gratefully acknowledge the supply of materials by Imerys ${ }^{\circledR}$ and Rockwood Lithium ${ }^{\circledR}$.

\section{References}

1. R. Wagner, N. Preschitschek, S. Passerini, J. Leker and M. Winter, Journal of Applied Electrochemistry, 2013, 43, 481-496. http://dx.doi.org/10.1007/s10800-013-0533-6

2. M. N. Obrovac and L. Christensen, Electrochemical and Solid State Letters, 2004, 7, A93-A96. http://dx.doi.org/10.1149/1.1652421

3. S. Hossain, Y. K. Kim, Y. Saleh and R. Loutfy, J. Power Sources, 2003, 114, 264-276. http://dx.doi.org/10.1016/S0378-7753(02)00588-8

4. F. Courtel, H. Duncan and Y. Abu-Lebdeh, in Nanotechnology for Lithium-Ion Batteries, eds. Y. Abu-Lebdeh and I. Davidson, Springer US, 2013, ch. 5, pp. 85-116.

5. N. Nitta, F. Wu, J. T. Lee and G. Yushin, Materials Today, 2015, 18, 252-264. http://dx.doi.org/10.1016/j.mattod.2014.10.040

6. J. P. Olivier and M. Winter, Journal of Power Sources, 2001, 97-8, 151-155.

http://dx.doi.org/10.1016/S0378-7753(01)00527-4

7. D. Bresser, E. Paillard, E. Binetti, S. Krueger, M. Striccoli, M. Winter and S. Passerini, Journal of Power Sources, 2012, 206, 301-309.

http://dx.doi.org/10.1016/j.jpowsour.2011.12.051

8. D. Bresser, E. Paillard, M. Copley, P. Bishop, M. Winter and S. Passerini, Journal of Power Sources, 2012, 219, 217-222. http://dx.doi.org/10.1016/j.jpowsour.2012.07.035

9. K. W. Leitner, J. O. Besenhard and M. Winter, Journal of Power Sources, 2005, 146, 209-212.

http://dx.doi.org/10.1016/j.jpowsour.2005.03.140

10. J. O. Besenhard, J. Yang and M. Winter, Journal of Power Sources, 1997, 68, 87-90. http://dx.doi.org/10.1016/S0378-7753(96)02547-5

11. M. Winter and J. O. Besenhard, Electrochimica Acta, 1999, 45, 31-50.

http://dx.doi.org/10.1016/S0013-4686(99)00191-7 
12. H. Jia, R. Kloepsch, X. He, J. P. Badillo, P. Gao, O. Fromm, T. Placke and M. Winter, Chemistry of Materials, 2014, 26, 5683-5688. http://dx.doi.org/10.1021/cm5025124

13. M. Winter, J. O. Besenhard, J. H. Albering, J. Yang and M. Wachtler, M. Prog. Batteries Battery Mater., 1998, 17, 208214.

14. J. Cabana, L. Monconduit, D. Larcher and M. Rosa Palacin, Adv. Mater, 2010, 22, E170-E192.

http://dx.doi.org/10.1002/adma.201000717

15. M. V. Reddy, G. V. Subba Rao and B. V. R. Chowdari, Chemical Reviews, 2013, 113, 5364-5457.

http://dx.doi.org/10.1021/cr3001884

16. J. O. Besenhard, M. Wachtler, M. Winter, R. Andreaus, I. Rom and W. Sitte, Journal of Power Sources, 1999, 81-82, 268-272. http://dx.doi.org/10.1016/S0378-7753(99)00199-8

17. W.-M. Zhang, X.-L. Wu, J.-S. Hu, Y.-G. Guo and L.-J. Wan, Adv. Funct. Mater., 2008, 18, 3941-3946. http://dx.doi.org/10.1002/adfm.200801386

18. Y. Ding, Y. Yang and H. Shao, Electrochimica Acta, 2011, 56, 9433-9438. http://dx.doi.org/10.1016/j.electacta.2011.08.031

19. Y. Deng, Q. Zhang, S. Tang, L. Zhang, S. Deng, Z. Shi and G. Chen, Chemical Communications, 2011, 47, 6828-6830. http://dx.doi.org/10.1039/c0cc05001f

20. D. Bresser, E. Paillard, R. Kloepsch, S. Krueger, M. Fiedler, R. Schmitz, D. Baither, M. Winter and S. Passerini, Adv. Energy Mater, 2013, 3, 513-523.

http://dx.doi.org/10.1002/aenm.201200735

21. A. Brandt, F. Winter, S. Klamor, F. Berkemeier, J. Rana, R. Pottgen and A. Balducci, J. Mater. Chem. A, 2013, 1, 11229-11236. http://dx.doi.org/10.1039/c3ta11821e

22. D. Larcher, C. Masquelier, D. Bonnin, Y. Chabre, V. Masson, J. B. Leriche and J. M. Tarascon, Journal of the Electrochemical Society, 2003, 150, A133-A139. http://dx.doi.org/10.1149/1.1528941

23. Y. Ren, A. R. Armstrong, F. Jiao and P. G. Bruce, Journal of the American Chemical Society, 2010, 132, 996-1004. http://dx.doi.org/10.1021/ja905488x

24. D. Pasero, N. Reeves and A. R. West, Journal of Power Sources, 2005, 141, 156-158.

http://dx.doi.org/10.1016/j.jpowsour.2004.07.037

25. Y. Yang, Y. Zhao, L. Xiao and L. Zhang, Electrochem. Commun., 2008, 10, 1117-1120.

http://dx.doi.org/10.1016/j.elecom.2008.05.026

26. Y. Sharma, N. Sharma, G. V. S. Rao and B. V. R. Chowdari, Adv. Funct. Mater., 2007, 17, 2855-2861. http://dx.doi.org/10.1002/adfm.200600997

27. Y. Wang, H. Xia, L. Lu and J. Lin, ACS Nano, 2010, 4, 1425-1432. http://dx.doi.org/10.1021/nn9012675

28. P. Poizot, S. Laruelle, S. Grugeon, L. Dupont and J. M. Tarascon, Nature, 2000, 407, 496-499. http://dx.doi.org/10.1038/35035045

29. A. Tomitaka, A. Hirukawa, T. Yamada, S. Morishita and Y. Takemura, Journal of Magnetism and Magnetic Materials, 2009, 321, 1482-1484. http://dx.doi.org/10.1016/j.jmmm.2009.02.058
30. J. Q. Wang, P. King and R. A. Huggins, Solid State Ionics, 1986, 20, 185-189. http://dx.doi.org/10.1016/0167-2738(86)90212-2

31. F. Belliard, P. A. Connor and J. T. S. Irvine, Solid State Ionics, 2000, 135, 163-167. http://dx.doi.org/10.1016/S0167-2738(00)00296-4

32. F. Belliard and J. T. S. Irvine, Journal of Power Sources, 2001, 97-8, 219-222. http://dx.doi.org/10.1016/S0378-7753(01)00544-4

33. C. J. Chen, M. Greenblatt and J. V. Waszczak, Solid State Ionics, 1986, 18-9, 838-846. http://dx.doi.org/10.1016/0167-2738(86)90273-0

34. Y. N. NuLi, Y. Q. Chu and Q. Z. Qin, Journal of the Electrochemical Society, 2004, 151, A1077-A1083. http://dx.doi.org/10.1149/1.1760576

35. Y. F. Deng, Q. M. Zhang, S. D. Tang, L. T. Zhang, S. N. Deng, Z. C. Shi and G. H. Chen, Chem. Commun., 2011, 47, 6828-6830. http://dx.doi.org/10.1039/c0cc05001f

36. X. W. Guo, X. Lu, X. P. Fang, Y. Mao, Z. X. Wang, L. Q. Chen, X. X. Xu, H. Yang and Y. N. Liu, Electrochem. Commun., 2010, 12, 847-850. http://dx.doi.org/10.1016/j.elecom.2010.04.003

37. Z. Xing, Z. C. Ju, J. Yang, H. Y. Xu and Y. T. Qian, Nano Res., 2012, 5, 477-485. http://dx.doi.org/10.1007/s12274-012-0233-2

38. P. F. Teh, Y. Sharma, S. S. Pramana and M. Srinivasan, $J$. Mater. Chem., 2011, 21, 14999-15008. http://dx.doi.org/10.1039/c1jm12088c

39. N. N. Wang, H. Y. Xu, L. Chen, X. Gu, J. Yang and Y. T. Qian, Journal of Power Sources, 2014, 247, 163-169. http://dx.doi.org/10.1016/j.jpowsour.2013.08.109

40. Y. Sharma, N. Sharma, G. V. S. Rao and B. V. R. Chowdari, Electrochim. Acta, 2008, 53, 2380-2385. http://dx.doi.org/10.1016/j.electacta.2007.09.059

41. W. Man, A. Zhihui and Z. Lizhi, J. Phys. Chem. C, 2008, 112, 13163-13170. http://dx.doi.org/10.1021/jp804009h

42. X. H. Hou, X. Y. Wang, L. M. Yao, S. J. Hu, Y. P. Wu and X. Liu, New Journal of Chemistry, 2015, 39, 1943-1952. http://dx.doi.org/10.1039/C4NJ01535E

43. L. Lian, L. R. Hou, L. Zhou, L. S. Wang and C. Z. Yuan, Rsc Advances, 2014, 4, 49212-49218. http://dx.doi.org/10.1039/C4RA08227C

44. Z. Hongliang, G. Xiaoyun, Z. Diantai, W. Zhengkai, W. Naiyan and Y. Kuihong, Nanotechnol., 2008, 19, 405503405507. http://dx.doi.org/10.1088/0957-4484/19/40/405503

45. Y. Ding, Y. F. Yang and H. X. Shao, Electrochim. Acta, 2011, 56, 9433-9438. http://dx.doi.org/10.1016/j.electacta.2011.08.031

46. T. Xu, X. Zhou, Z. Y. Jiang, Q. Kuang, Z. X. Xie and L. S. Zheng, Cryst. Growth Des., 2009, 9, 192-196. http://dx.doi.org/10.1021/cg8002096

47. R. J. Zhang, J. J. Huang, H. T. Zhao, Z. Q. Sun and Y. Wang, Energy Fuels, 2007, 21, 2682-2687. http://dx.doi.org/10.1021/ef070064w 
48. P. Lavela and J. L. Tirado, Journal of Power Sources, 2007, 172, 379-387. http://dx.doi.org/10.1016/j.jpowsour.2007.07.055

49. Y. Zhou and M. Antonietti, J. Am. Chem. Soc., 2003, 125, 14960-14961. http://dx.doi.org/10.1021/ja0380998

50. Y. J. Zhu, W. W. Wang, R. J. Qi and X. L. Hu, Angew. Chem.Int. Edit., 2004, 43, 1410-1414. http://dx.doi.org/10.1002/anie.200353101

51. W. Xing, J. S. Xue and J. R. Dahn, Journal of the Electrochemical Society, 1996, 143, 3046-3052. http://dx.doi.org/10.1149/1.1837162

52. T. Placke, G. Schmuelling, R. Kloepsch, P. Meister, O.Fromm, P. Hilbig, H.W. Meyer and M. Winter, Z. Anorg. Allg. Chem, 2014, 640, 1996-2006. http://dx.doi.org/10.1002/zaac.201400181

53. R. R. Chianelli, J. C. Scanlon and B. M. L. Rao, J. Electrochem. Soc., 1978, 125, 1563-1566. http://dx.doi.org/10.1149/1.2131244

54. M. Morcrette, Y. Chabre, G. Vaughan, G. Amatucci, J. B. Leriche, S. Patoux, C. Masquelier and J. M. Tarascon, Electrochimica Acta, 2002, 47, 3137-3149. http://dx.doi.org/10.1016/S0013-4686(02)00233-5

55. R. R. Gandhi, S. Gowri, J. Suresh and M. Sundrarajan, J. Mater. Sci. Technol., 2013, 29, 533-538. http://dx.doi.org/10.1016/j.jmst.2013.03.007

56. F. A. López, A. López-Delgado, J. L. Martín de Vidales and E. Vila, Journal of Alloys and Compounds, 1998, 265, 291296. http://dx.doi.org/10.1016/S0925-8388(97)00282-X

57. R. I. R. Blyth, H. Buqa, F. P. Netzer, M. G. Ramsey, J. O. Besenhard and M. Winter, Journal of Power Sources, 2001, 97-8, 171-173. http://dx.doi.org/10.1016/S0378-7753(01)00540-7

58. A. Gibaud, J. S. Xue and J. R. Dahn, Carbon, 1996, 34, 499-503. http://dx.doi.org/10.1016/0008-6223(95)00207-3

59. A. Gupta and I. R. Harrison, Carbon, 1994, 32, 953-960. http://dx.doi.org/10.1016/0008-6223(94)90055-8

60. M. V. Reddy, T. Yu, C. H. Sow, Z. X. Shen, C. T. Lim, G. V. S. Rao and B. V. R. Chowdari, Advanced Functional Materials, 2007, 17, 2792-2799. http://dx.doi.org/10.1002/adfm.200601186

61. S. Liu, J. Xie, C. Fang, G. Cao, T. Zhu and X. Zhao, J. Mater. Chem., 2012, 22, 19738-19743. http://dx.doi.org/10.1039/c2jm34019d

62. J. Xie, W. Song, G. Cao, T. Zhu, X. Zhao and S. Zhang, Rsc Advances, 2014, 4, 7703-7709.

http://dx.doi.org/10.1039/c3ra46904b

63. M. M. Thackeray, W. I. F. David and J. B. Goodenough, Materials Research Bulletin, 1982, 17, 785-793. http://dx.doi.org/10.1016/0025-5408(82)90029-0

64. T. Fujieda, S. Takahashi and S. Higuchi, J. Power Sources, 1992, 40, 283-289. http://dx.doi.org/10.1016/0378-7753(92)80016-5

65. G. M. Zhou, D. W. Wang, F. Li, L. L. Zhang, N. Li, Z. S. Wu, L. Wen, G. Q. Lu and H. M. Cheng, Chem. Mat., 2010, 22, 5306-5313. http://dx.doi.org/10.1021/cm101532x

66. K. M. Shaju, F. Jiao, A. Debart and P. G. Bruce, Phys. Chem. Chem. Phys., 2007, 9, 1837-1842. http://dx.doi.org/10.1039/B617519H

67. G. Binotto, D. Larcher, A. S. Prakash, R. Herrera Urbina, M. S. Hegde and J. M. Tarascon, Chemistry of Materials, 2007, 19, 3032-3040. http://dx.doi.org/10.1021/cm070048c

68. D. R. Gallus, R. Schmitz, R. Wagner, B. Hoffmann, S. Nowak, I. Cekic-Laskovic, R. W. Schmitz and M. Winter, Electrochimica Acta, 2014, 134, 393-398.

http://dx.doi.org/10.1016/j.electacta.2014.04.091

69. M. Evertz, C. Lürenbaum, B. Vortmann, M. Winter and S. Nowak, Spectrochimica Acta Part B: Atomic Spectroscopy, 2015, 112, 34-39. http://dx.doi.org/10.1016/j.sab.2015.08.005

70. W. Choi and A. Manthiram, Journal of The Electrochemical Society, 2006, 153, A1760-A1764. http://dx.doi.org/10.1149/1.2219710

71. W. Dreyer, J. Jamnik, C. Guhlke, R. Huth, J. Moskon and M. Gaberscek, Nat Mater, 2010, 9, 448-453.

http://dx.doi.org/10.1038/nmat2730

\section{Povzetek}

To delo opisuje uspešno sintezo z ogljikom prevlečenega anodnega materiala $\mathrm{ZnFe}_{2} \mathrm{O}_{4}$ s pomočjo ionskih tekočin. Sintetizirani material $\mathrm{ZnFe}_{2} \mathrm{O}_{4}$ izkazuje ozko porazdelitev delcev v razponu od 40 do $80 \mathrm{~mm}$. Material nudi zanimivo kombinacijo mehanizmov legiranja in konverzije in je zmožen sprejeti devet ekvivalentov litija na enoto formule, kar se

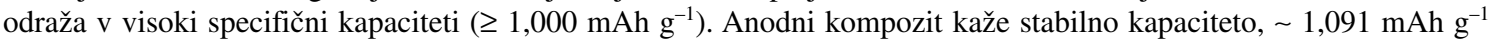
190 ciklov, pri srednjem de-litiacijskem potencialu 1.7V ter hitrosti polnjenja in praznenja 1C. Nadalje, material izkazuje odlične lastnosti pri visokih tokovnih obremenitvah (20C) in kaže stabilno reverzibilno kapaciteto $216 \mathrm{mAh} \mathrm{g}^{-1}$. Narejene so bile študije korozije $\mathrm{Fe}$ in $\mathrm{Zn} \mathrm{v}$ aktivnem materialu $\mathrm{ZnFe}_{2} \mathrm{O}_{4}$ ter primerjane $\mathrm{z}$ anodnim materialom $\mathrm{z}$ visoko kapaciteto na osnovi silicija, germanija in kositra. Na podlagi rezultatov ugotavljamo, da igra korozija kovin iz anodnega materiala veliko vlogo pri celokupnem odzivu baterije in stabilnosti praznjenja in polnenja. 